\title{
An early-Holocene Aboriginal coastal landscape at Cape Duquesne, southwest Victoria, Australia
}

\author{
Thomas Richards \\ School of Geography and Environmental Science, Monash University, Clayton, Victoria \\ thomas.richards@monash.edu
}

\section{Introduction}

Peter Kershaw has contributed substantially to the understanding of palaeoenviromental change in Australia, particularly in relation to the timing of Aboriginal colonisation and anthropomorphic alterations of vegetation communities. More recently, Kershaw and colleagues have studied the palaeoenvironment of southwestern Victorian landscapes, with emphasis on the palaeoecology of lakes and swamps, especially in regard to the appearance of Aboriginal water management and fish-trapping systems on the Mt Eccles lava flow and the relationship of these systems to socioeconomic complexity of Aboriginal groups in the southwest (e.g. Kershaw 2004; Tibby et al. 2006; Builth et al. 2008; Kershaw and Lewis 2011). This chapter addresses similar issues of Aboriginal social complexity in southwest Victoria, but examines them from a nearby coastal landscape perspective.

There has been controversy regarding the complexity of Aboriginal societies in southwest Victoria since the 1880s, with disagreement focused on the nature of leadership in the ethnographic period (e.g. Dawson 1881, 1887; Curr 1886; Howitt 1887, 1904; Corris 1968; Lourandos 1977, 1980a, b, 1983, 1984, 1987, 1997; Barwick 1984; Williams 1985, 1987; Critchett 1990, 1998; Edwards 1987; Hiatt 1996; Keen 2006; Hayden 2006) and expanding a century later into debates regarding Lourandos's socioeconomic intensification modelling for the late-Holocene (e.g. Lourandos 1980a, 1983, 1985a, b, 1988, 1993, 1996, 1997; Beaton 1983, 1985; McBryde 1984; Williams 1985, 1987, 1988; Godfrey 1989; Bird and Frankel 1991a,b, 1998, 2005; Lourandos and Ross 1994; Bird et al. 1998, 1999; McNiven et al. 1999; David et al. 2006; Keen 2006; Hiscock 2008). 'Complex', 'affluent', or 'transegalitarian' foragers or huntergatherers are societies thought to exhibit characteristics of cultural and social complexity that contrast with an idealised view of egalitarian, highly mobile hunter-gatherers (Koyama and 


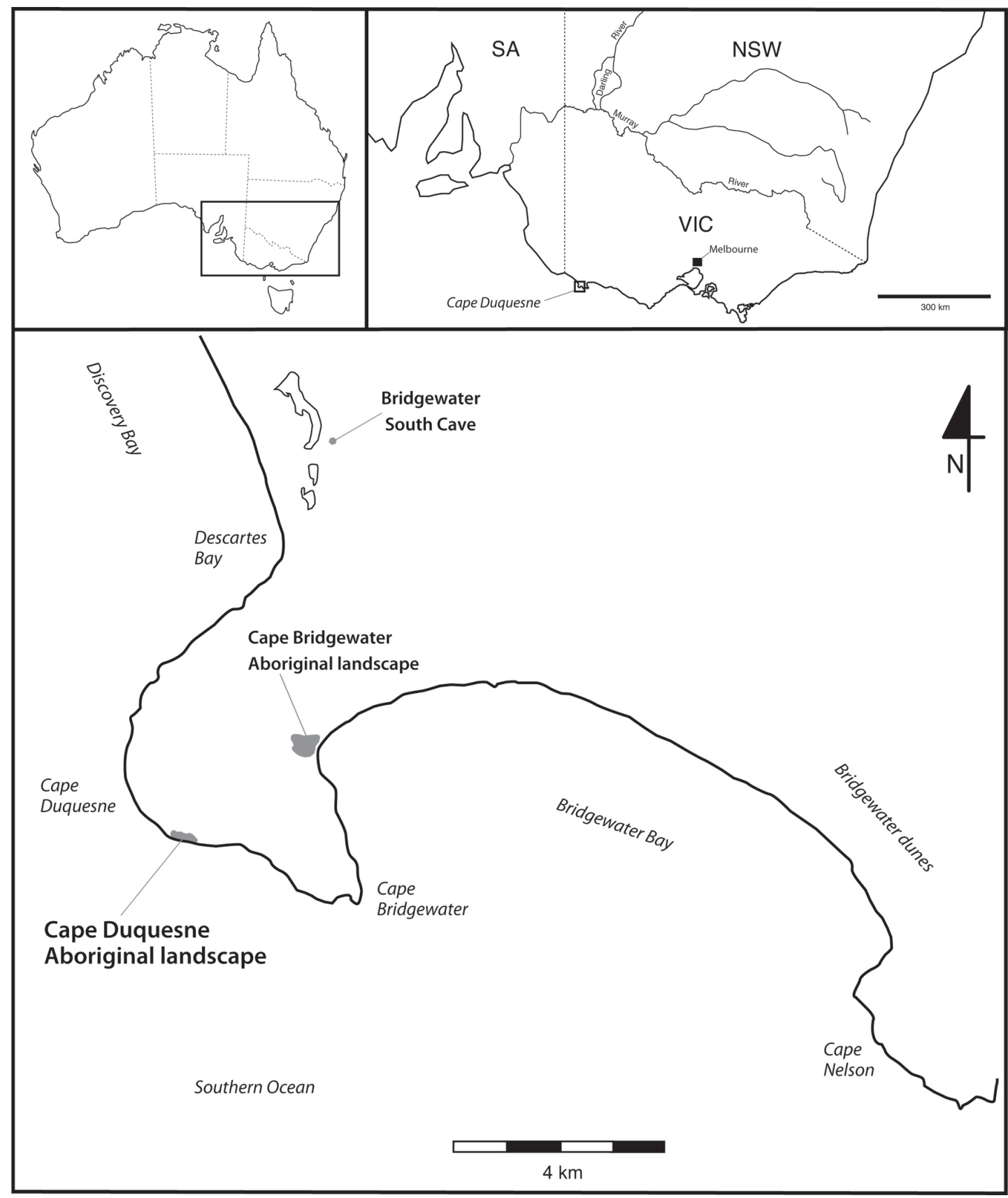

Figure 1. Location of Cape Duquesne Aboriginal landscape in southwest Victoria, Australia.

Thomas 1981; Price and Brown 1985; Hayden 1995; Grier et al. 2006):

Transegalitarian societies are societies that are neither egalitarian nor politically stratified; they are thus intermediate between generalized hunter-gatherers and chiefdoms in terms of the social and economic inequalities that characterize them. (Owens and Hayden 1997:121)

While much of the debate regarding transegalitarian features in the archaeological record of southwest Victoria has revolved around Aboriginal water control and eel management infrastructure, and earth mounds, Aboriginal marine shell middens are a major source of contention in the region, with Lourandos (1983, 1993, 1997:224-227; Lourandos and Ross 1994:58-59) documenting the increasing use and establishment of middens from ca. 3500 years 
ago as evidence in support of his intensification model, although this is disputed by some other researchers (e.g. Godfrey 1989; Bird and Frankel 1991a, b; Hiscock 2008:190-191). Missing from these discussions have been comparisons between the structure and contents of lateHolocene middens and earlier middens, due to the absence of data from formally excavated early-Holocene middens in the region.

Excavations on an Aboriginal landscape at Cape Duquesne provide crucial evidence for early-Holocene coastal occupation in this region and this paper will document the chronology, contents and structure of several excavated middens from this period and characterise midden deposition rates and littoral resource exploitation patterns (Figure 1). This baseline data set for the early-Holocene will be compared with data from the late-Holocene as an additional means of evaluating possible late-Holocene changes in coastal resource use related to or reflecting increased complexity in regional societies.

Before the Cape Duquesne Aboriginal landscape data are presented, the regional archaeological context and local environmental setting are briefly reviewed.

\section{Previous archaeology}

Over the past four decades, numerous researchers have focused on the southwest Victoria and adjacent southeast South Australia coastal region (e.g. Lourandos 1976, 1980a, 1983, 1997; Witter 1977; Clark 1979; Godfrey 1980,1984, 1989, 1994, 1996, 2000; Godwin 1980; Wesson and Clark 1980; Simmons and Djekic 1981; Head 1985; Frankel 1986, 1991; Cann et al. 1991; Webb 1995; Richards and Jordan 1996; Everett 1998; Schell 2000a, b; Bird and Frankel 2001; Debney and Cekalovik 2001; Richards and Johnston 2004; Richards and Webber 2004). Yet excavation data for the early-Holocene is limited to two well-researched sites - Bridgewater South Cave and Koongine Cave.

Bridgewater South Cave, only $8 \mathrm{~km}$ north of Cape Duquesne, was excavated by Lourandos in the mid 1970s (1976,1980a, 1983,1997). The site consists of superficially disturbed stratified deposits both inside and in front of a medium-sized limestone rockshelter that had excellent preservation of organic material (see cover photograph of this volume). Of interest here is the late-Pleistocene-early-Holocene occupation evidence within stratigraphic Phase A, dating between ca. 13,250 cal BP and ca. 9350 cal BP (Table 1) (Lourandos 1983:83; Head 1985:5):

During this phase there is an over-riding emphasis on land mammals that consisted of a substantial proportion of macropods (including the grey kangaroo) and wombat. There was correspondingly very little representation of marine foods. Apart from scattered pieces of shell of both sandy beach and ocean rock platform species there was evidence of one seal and one fish. Flaked stone was in low frequency... (Lourandos 1980a:348)

Lourandos (1980a:349-350) characterises occupation during Phase A as likely to have occurred during autumn-winter, with the evidence suggesting '...an ephemeral use of the site as a hunting bivouac...' (Lourandos 1997:201-202).

Although currently $1.5 \mathrm{~km}$ from the sea in a straight line, Bridgewater South Cave would have been ca. $3.75 \mathrm{~km}$ from the Discovery Bay coastline at 11,000 cal BP, ca. $3.0 \mathrm{~km}$ at 10,000 cal BP and only ca. $2.25 \mathrm{~km}$ by $9000 \mathrm{cal} \mathrm{BP}$, thus within easy reach of the shoreline; however, it is apparent that decisions were made not to exploit coastal resources from this camp, with the major exception of a high-value resource such as seals.

In several ways, Koongine Cave is a twin of Bridgewater South Cave, located at the opposite end of Discovery Bay, some $85 \mathrm{~km}$ to the northwest (Bird and Frankel 2001:74). It is also a 
Table 1. Calibrated radiocarbon age determinations for southwest Victorian and southeast South Australian late-Pleistocene and early-Holocene Aboriginal coastal sites discussed in paper (other than Cape Duquesne).

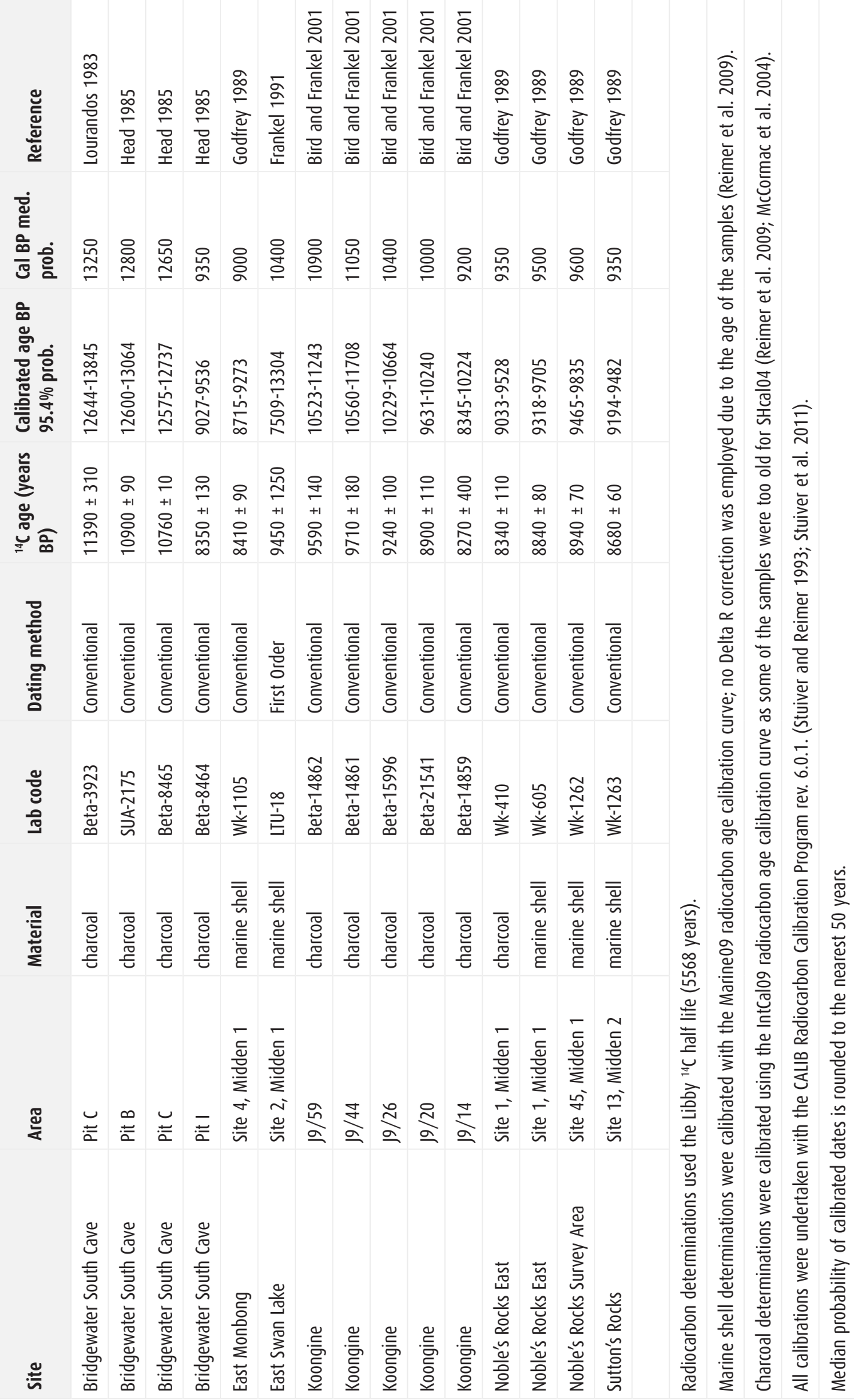


substantial limestone cave set in a scarp on the edge of the coastal plain, containing significant early-Holocene occupation deposits, and has a well-preserved faunal assemblage.

Both the early and middle phases of occupation (ca. 11,000-9000 cal BP) are interpreted as representing repeated camping events during which a range of medium and small land mammals, including possums, bandicoots, potoroo, wallabies and wombats, and large mammals such as grey kangaroo, were hunted (Bird and Frankel 2001:71). In this sense, the period of occupation and the faunal assemblage is remarkably similar to that documented at Bridgewater South Cave (Lourandos 1980a: Table 13:2, 1983:83; Head 1985:5). The middle phase is essentially a less intensive version of the early phase, characterised by shorter and less frequent occupation episodes (Bird and Frankel 2001:74).

Although the shoreline would have been 10-15 km distant during the early and middle phases, a small amount of marine mollusc shell was recovered from Koongine Cave (Bird and Frankel 2001:73), as at Bridgewater South Cave. Finally, it is inferred from the presence of emu eggshell that occupation occurred in winter, although additional seasonal usage is possible (Bird and Frankel 2001:74) - yet another similarity to Bridgewater South Cave (Lourandos 1980a:352).

For Discovery Bay and Cape Bridgewater coastal sites, Godfrey $(1989,1994)$ and Frankel (1991) have used spot samples of marine shell from deflated middens for radiocarbon dating, producing several early-Holocene age determinations (Table 1). Unfortunately, this type of uncontrolled sampling does not provide a reliable basis for characterising the composition of faunal assemblages, as surface shell species proportions at Cape Duquesne are typically not representative of nearby deposits as revealed through excavation (see surface vs. excavated shell species proportions for shell midden investigations reported in this chapter). The itinerant dating approach of Godfrey and Frankel tells us only that early-Holocene Aboriginal coastal occupation of this region probably did occur, but little about the nature of this occupation.

\section{Landscape description and environment}

The study area is located in a very exposed position along the top of steep cliffs at Cape Duquesne, a headland at the southwestern tip of Cape Bridgewater on the Portland Peninsula (Figures 1,2). This is a high-energy coast dominated by swell waves and winds from the west through south-southwest (Short 1988:125; Buckley 1992:13).

Geomorphology, geology and soils

The Portland Peninsula is a large promontory jutting southward into the Southern Ocean, tipped by a sequence of protruding headlands and indented bays. Cape Duquesne is the westernmost of the headlands and is bounded by the extensive northwest-southeast trending Discovery Bay to the west, and the much smaller, protected Bridgewater Bay to the east. The juncture of Cape Duquesne with Discovery Bay is known as Descartes Bay.

Coastal geomorphology is dominated by three major geological formations exposed in cliff faces and on the surface - Plio-Pleistocene basalts and tuffs of the Newer Volcanic Formation, overlain by Pleistocene beach and dune calcarenites of the Bridgewater Formation and capped by terminal Pleistocene-Holocene dune sands (Boutakoff 1963; Bird 1993:24) (Figures 2-4). Much of this sequence is exposed in 25-120 m high vertical cliffs extending from Descartes Bay in the northwest, around the Cape Duquesne and Cape Bridgewater headlands to the south, and east and northeast into Bridgewater Bay. The present shoreline is mainly sheer basalt cliff, with the occasional small sandy beach (e.g. White's Beach to the northwest), narrow shingle, boulder talus or sea caves (e.g. Seal Cave to the east). There are also frequent off-shore intertidal basalt platforms. 


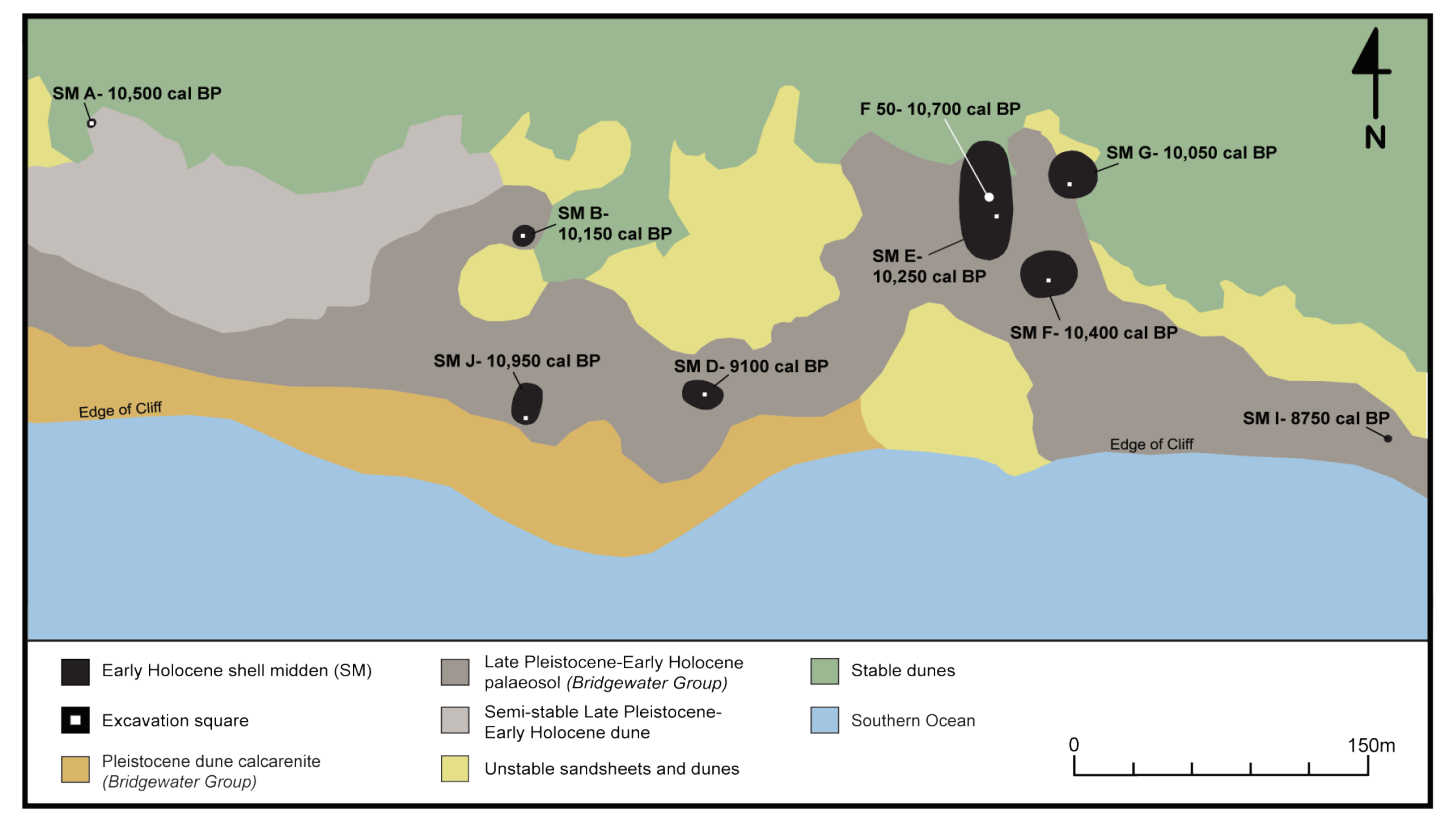

Figure 2. Exposed strata on Cape Duquesne Aboriginal landscape, showing the earliest calibrated radiocarbon age determination (median probability) for each dated midden and feature and the location of excavation squares.

Boutakoff (1963:48-51) defined the Bridgewater Formation, which consisted of a series of lithified calcareous sand dunes ('limestone dunes'), formed on sand derived from weathering of Tertiary dunes exposed by regressing seas during Pleistocene glacial periods, and also included palaeosols capping the calcarenite dunes. The latter, which were classed as rendzina, terra ross $a$ and laterite fossil soils, were considered to have formed following calcification of the underlying dunes during interstadial/interglacial pluvial conditions (Boutakoff 1963:49). They were described as calcareous, sandy and red, reddish-brown or reddish-pink soils (Boutakoff 1963:51). Subsequent research in the region confirmed Boutakoff's sequence (e.g. Kenley 1976; Douglas 1979; Land Conservation Council 1981), until Cupper et al. (2003:343-344) upgraded the Bridgewater Formation to the Bridgewater Group and expanded its distribution more broadly across southwestern Victoria.

Shortly after Boutakoff's (1963) geological study appeared, Gibbons and Downes (1964) published a study of soils along the southwest coast of Victoria. They described a terra rossa soil, the Nelson Sandy Loam, and a rendzina soil, the Bridgewater Sandy Loam, both with parent materials attributed to Pleistocene dune limestone or aeolianite of the Bridgewater Formation (Gibbons and Downes 1964: Appendix 1). Nelson Sandy Loam is a dark reddishbrown (2.5YR 2/4-3/4 wet) sandy loam, with a weak fine sub-angular blocky and fine crumb structure, loose to very friable, very porous and with a $\mathrm{pH}$ of 6.6 to 7.8 (Gibbons and Downes 1964: Appendix 1). Bridgewater Sandy Loam is a very dark brown (5 to 7.5YR 2/2) sandy loam, with a moderate medium crumb structure to sub-angular blocky structure, friable, and with a $\mathrm{pH}$ of 8.5 to 8.9 (Gibbons and Downes 1964:Appendix 1). They described one further soil of relevance, Discovery Bay Sand, found in high and unstable sand dunes, as a light yellowish brown (7.5YR to 10YR 7/4 dry, 6/4 moist) coarse sand composed mostly of calcium carbonate (finely broken seashells), with massive structure, loose, no organic matter, and a $\mathrm{pH}$ of 8.9 to 9.4 (Gibbons and Downes 1964:Appendix 1).

The Land Conservation Council (1981:14-15) described soils developed on dune limestone in the region as 'Red-black, uniform-gradational, sandy loams (terra rossa) ... generally shallow, with a crumb structure, friable throughout, and ... little horizon differentiation'. The Land Conservation Council (1981:14) study also describes 'Undifferentiated Calcareous Sands' generally found in extensive unconsolidated to mobile dunes, formed on sands moved onshore 


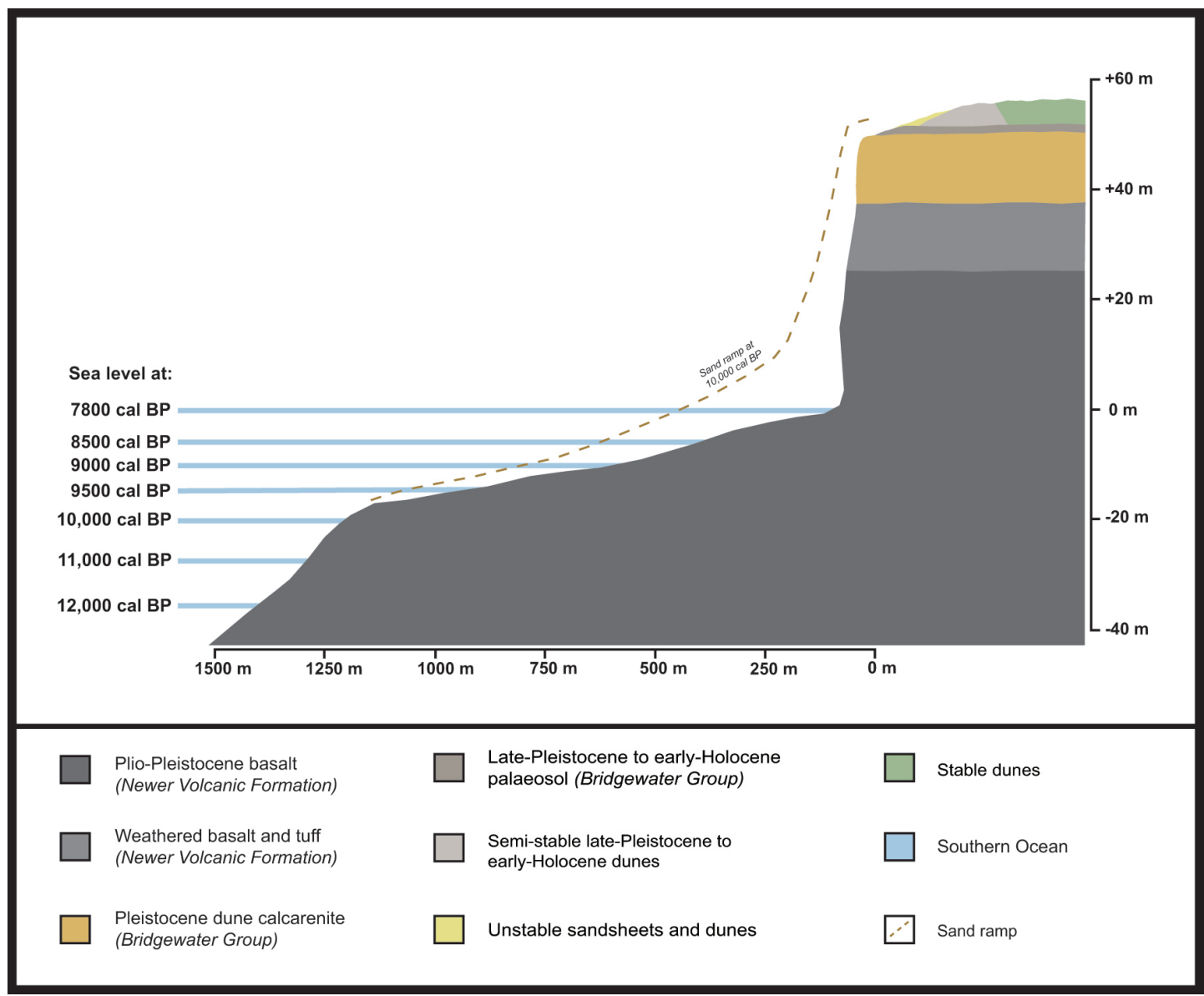

Figure 3. Cross-section through Cape Duquesne Aboriginal landscape and sea bed, showing sea levels (Sloss et al. 2007), geology (Boutakoff 1963) and the early-Holocene sand ramp (Short 1988). Vertical exaggeration $12.5 \mathrm{x}$.

from the continental shelf and reworked by wind action. These sands were characterised as yellow-brown, with little clay or organics, loose and structureless and extremely alkaline (Land Conservation Council 1981:14).

The Coastal Management and Co-ordination Committee report (1981:29) described the Holocene Bridgewater Bay mobile to stabilised dunes as overlying Pleistocene calcarenites; they comprise friable, uniform calcareous sand with little or no soil formation and a $\mathrm{pH}$ of up to 9.5 .

More recently, Buckley (1992) studied coastal beach and dune sediments from southwest Victoria in detail. He mentioned unconsolidated Holocene dune sands overlying Pleistocene calcarenite, notably the stranded clifftop dunes at Cape Bridgewater, and his analysis of Discovery Bay beach sands is very relevant to understanding of the origin of the clifftop sediments (Buckley 1992:13-20). He concluded that the majority of sand found on the Discovery Bay beaches was derived from calcareous continental shelf deposits moved landward during Pleistocene glacial phases (Buckley 1992:20). The sands were described as grey-brown, well sorted (0.44 phi), fine-medium calcareous sand, with a mean grain size of $0.26 \mathrm{~mm}$ and a carbonate content of 75\% (Buckley 1992:15-20).

In the recent synthetic overview by Cupper et al. (2003:343), the Bridgewater Group included the palaeosol horizons derived from pedogenesis and weathering of aeolian calcarenite surfaces first identified by Boutakoff. Overlying the Bridgewater Group are the Holocene Discovery Bay and Bridgewater Bay Sands, a composite of earlier work (e.g. Gibbons and Downes 1964; Kenley 1976; Land Conservation Council 1981). These sands were found in unconsolidated calcareous sandy beach, foredune and dune complexes, and were summarised 
as fine-grained, cream to white calcareous sand (Cupper et al. 2003:344).

Rosengren (2001a, b) carried out an applied geological study of Cape Bridgewater and Cape Duquesne for a wind-farm development. He reviewed the previously reported geology, and reconfirmed Boutakoff's Pleistocene dune limestone Bridgewater Formation. He attributed the limestone calcrete to Oxygen Isotope Stages (OIS) 5 to 2, and noted that dunes formed during OIS 2 to 1 had much slower rates of cementation than in previous Stages (Rosengren 2001a:213-215). Reddish-brown silty and clayey sands overlying calcrete, characterised as terra rossa and rendzina palaeosols, were again observed, as were poorly consolidated calcareous sands and clifftop dunes (Rosengren 2001a:213-215). The calcareous sands, of estimated OIS 2 to 1 age, were described as poorly differentiated to gradational, yellowish-brown sands, with only minor surface organic matter accumulation (Rosengren 2001a:214-215).

\section{Palaeoenvironment}

According to Kershaw et al. (2004:158), a decline in effective moisture in the terminal Pleistocene, largely due to rising temperatures, culminated in a period of maximum aridity from ca. 17,000-14,000 cal BP, during which woody plants were uncommon. In the succeeding period, ca. 14,000-11,500 cal BP, increases in both temperature and rainfall resulted in an expansion of the distribution of trees, accompanied by a change from steppe grassland to grassland (Kershaw et al. 2004:158). By the beginning of the Holocene, 11,500 cal BP, tree cover had reached early 19th century levels (pre-European clearing) (Kershaw et al. 2004:158). Vegetation community composition continued to change, with a sustained increase in Eucalyptus relative to Casuarinacea trees around 8900-7800 cal BP, so that essentially the vegetation cover present in the early 19th century, dry sclerophyll forest/woodland, was established by the end of this period (Kershaw et al. 2004:139,158-159).

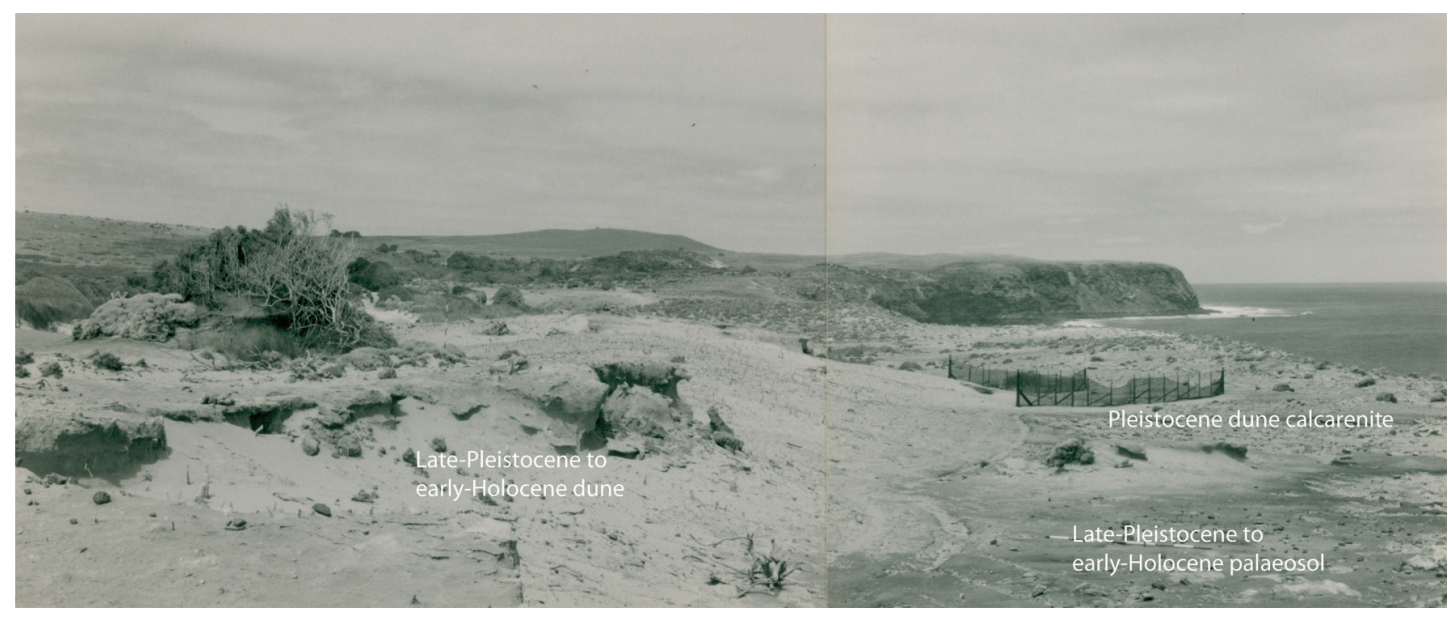

Figure 4. View east from western end of landscape, showing surface exposure of strata, including the actively eroding dune formed in the late-Pleistocene and early-Holocene, the exposed late-Pleistocene early-Holocene palaeosol and Pleistocene dune calcarenite. A remnant sediment pedestal can be seen on the left top of the dune and numerous carbonate root casts are exposed all over the eroding face of the dune.

\section{Cape Duquesne investigations}

Investigations at Cape Duquesne (AAV 7121/233) have revealed a series of open-air Aboriginal shell midden deposits at the top of a $50 \mathrm{~m}$ high cliff, with the ocean currently washing against its base (Figures 2-4). As noted in the previous section, vast areas of carbonate sands were exposed on the continental shelf along southern Australia during the late Pleistocene and much of this sand was mobilised as the high-energy sea transgressed and strong southwesterly winds prevailed (Short 1988:121). These sands, mainly locally sourced 
from the exposed sea bed, piled up against obstructions such as the cliffs at Cape Duquesne, and occasionally overtopped these cliffs (Short 1988:138). During the terminal Pleistocene through early-Holocene, the resulting sand ramp would have extended from the exposed sea bed near the shoreline up and over the top of the Cape Duquesne cliffs, providing easy human access between the two locations. This explains the presence of marine shell middens at the top of the seemingly impassable barrier of the cliffs (Figure 3, Table 2). Later, the transgressing sea would have directly eroded the base of the ramp, removing it entirely as the current sea level was attained (and then exceeded), leaving the stranded clifftop dunes as the last remnant of the former ramp (Short 1988:138-139; Rosengren 2001a:215).

Table 2. Distance to shoreline from Cape Duquesne early-Holocene Aboriginal landscape (sea level curve of Sloss et al. 2007).

\begin{tabular}{|c|c|c|c|c|}
\hline $\begin{array}{l}\text { Years cal } \\
\text { BP }\end{array}$ & $\begin{array}{l}\text { Sea level }(m) \\
\text { (relative to } \\
\text { present) }\end{array}$ & C. Duquesne occupation & $\begin{array}{l}\text { Horizontal distance from } \\
\text { C. Duq. to shore }(\mathrm{m})\end{array}$ & $\begin{array}{l}\text { Vertical distance from C. } \\
\text { Duq. to shore (m) }\end{array}$ \\
\hline 12,000 & -35 & & 1384 & 90 \\
\hline 11,500 & -31 & pre-SM A & 1312 & 86 \\
\hline 11,000 & -27 & & 1275 & 82 \\
\hline 10,500 & -23 & F 50, SM J & 1236 & 78 \\
\hline 10,000 & -19 & $S M A, S M B, S M E, S M F, S M G$ & 1184 & 74 \\
\hline 9500 & -14 & SM A, SM G & 888 & 69 \\
\hline 9000 & -10 & SM D & 632 & 66 \\
\hline 8500 & -6 & SM I & 400 & 61 \\
\hline 8000 & -3 & & 240 & 58 \\
\hline 7800 & 0 & & 50 & 55 \\
\hline
\end{tabular}

Wind erosion has significantly shaped the Cape Duquesne landscape, so that the present surface is a patchwork of differentially exposed Pleistocene and Holocene landforms and sediments (Figures 2,3). There are extensive exposures of lithified dune deposits (calcarenite) along the southern edge of the landscape (the clifftop) in the centre and west of the landscape, where wind action has scoured away all overlying sediment. These are calcarenites of the Pleistocene Bridgewater Group.

Running approximately east-west across the landscape is an exposed palaeosol, comprising greyish sandy loam, most similar to the Bridgewater Sandy Loam, a rendzina soil (Gibbons and Downes 1964: Appendix 1). The sandy loam directly overlies the calcarenite, varying from mere remnant patches a few centimetres thick filling in hollows on uneven, calcarenite surfaces, to deposits more than $1 \mathrm{~m}$ thick. Such palaeosols are commonly associated with calcarenites of the Bridgewater Group and are considered part of this unit. In the present erosional situation, the palaeosols are again active soils, although generally very poorly vegetated.

Dominating the western end of the landscape is a large dune, for the most part actively eroding with little vegetation cover, but which is vegetated and stable to the north (Figure 4). Remnant sediment pedestals and exposed carbonate root casts indicate that more than $1 \mathrm{~m}$ of sand has been removed from the southern surface of this dune by wind action. This dune is a remnant of the clifftop dunes deposited since the Last Glacial Maximum (LGM), and much of the present eroding greyish-brown sandy surface is at least early-Holocene in age. It overlies both the sandy loam palaeosol and the calcarenites of the Bridgewater Group (Figures 2-4).

The vegetated area 50-150 $\mathrm{m}$ to the north of the cliff edge all along the landscape comprises the remaining stabilised clifftop dune field (Figure 2). Poorly vegetated sandsheets are present south of the dunefield in patches on the landscape, representing destabilised clifftop dunes reworked by wind action during the Holocene (Figure 2). 


\section{Archaeological survey and the surface record}

The area subject to detailed systematic archaeological survey, much of it deflated to some extent, extended $1 \mathrm{~km}$ along the clifftops and up to $400 \mathrm{~m}$ inland. The goal of the survey was to identify the extent of the Aboriginal landscape, focusing on the distribution of flaked and ground stone artefacts, shell middens, hearth features and other evidence of human occupation. The initial pedestrian survey identified the gross extent of the distribution of Aboriginal cultural material exposed on the surface -58 hearth features, eight shell middens and thousands of flaked stone artefacts were found over an area of approximately 500 m east-west and $125 \mathrm{~m}$ north-south $\left(62,500 \mathrm{~m}^{2}\right)$. The landscape was mapped, hearth features and shell middens were recorded in detail, three of the exposed hearth features were excavated and eight shell midden deposits were tested. None of the great numbers of lithic artefacts observed on the surface were in situ, so they were generally not mapped individually, although samples of stone artefacts, animal bones, marine shell, hearth stones, charcoal and sediments were mapped and collected for identification and analysis.

In situ shell midden deposits are only located on early-Holocene and late-Pleistocene features, namely clifftop dunes and sandy loam palaeosols capping calcarenite, while stone artefacts and deflated hearth features are distributed more widely across the landscape, suggesting. they mostly derive from more recent deposits that have largely eroded away. Technology of flaked stone artefacts and radiocarbon age determinations on two remnant hearth features indicate a substantial late-Holocene occupation across this landscape, but the focus of the present study is on the early-Holocene shell middens and hearth features.

Surface exposures of middens displayed obvious loose shells that were not in their primary context, but other shells appeared to be eroding out of the surface, due to wind removal of surrounding soil particles, and seemed to be in situ. Shell Midden A (SM A) was excavated first to determine whether in situ deposits were indeed present, to identify the subsurface structure and characteristics of the midden and to obtain samples for identification, analysis and chronometric dating.

\section{Excavation of Shell Midden A}

SM A is located at the northwestern corner of the landscape (Figure 2). It manifested on the surface as a dense concentration of Turbo undulata and Cellana tramoserica shells and a small amount of charcoal exposed by wind erosion (Figure 5). Some of the shells were loose, but what appeared to be an in situ shell deposit was eroding out of sediments below the loose shell and recently blown-in sand. The area of midden exposed on the ground surface measured approximately $3 \mathrm{~m}$ in diameter; however, it extended under partially consolidated dune deposits to the northwest and is probably many times larger in area than the exposed, eroding portion.

\section{Methods}

Square 1, measuring $1 \mathrm{~m} \times 1 \mathrm{~m}$ was staked out over the area, with the highest concentration of eroding midden material on the surface (Figure 5). All sediment was excavated with trowels and dry sieved through $3 \mathrm{~mm}$ mesh screens in the field (with the exception of bulk soil samples); all sieve residue was retained for cataloguing and analysis. The first step in the investigation involved the sweeping up and collecting of all loose material on the surface of the square. Although sorted and catalogued, this material has been excluded from the present analysis and discussion because it was not in situ. Two excavation units (XUs), each $5 \mathrm{~cm}$ deep, were dug with trowels across Square A. A third XU, also $5 \mathrm{~cm}$ deep, was dug in the northeast quadrant of the square. 


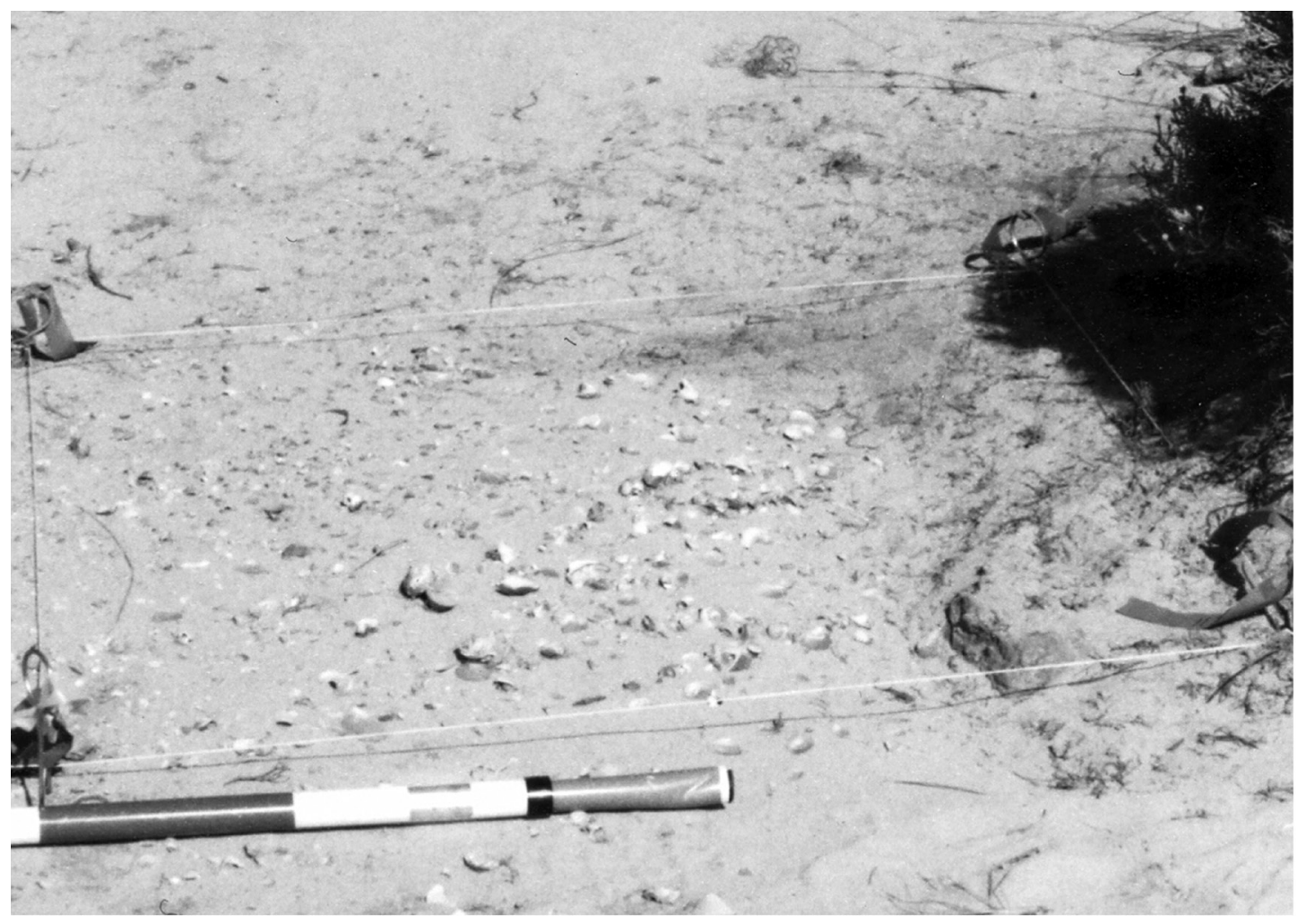

Figure 5. Shell Midden A, Square 1, pre-excavation view showing dense midden material on surface. Ranging pole bars are $20 \mathrm{~cm}$ long.

\section{Stratigraphy}

Excavation revealed a very dense deposit of whole and fragmented marine shellfish shell that extended across the square, with associated carbonate-coated chunks of charcoal and flaked stone, to an average depth of $4 \mathrm{~cm}$ below surface. Small amounts of shell and charcoal continued for another $2 \mathrm{~cm}$ in the unconsolidated sand (Figure 6). Below the base of the midden, a patch of burnt sediment and charcoal with an associated large flat rock (manuport) was uncovered in the northeast of the square and extended to $9 \mathrm{~cm}$ below surface. This feature is stratigraphically earlier than SM A.

Sediment in the midden deposit was an unconsolidated, dark greyish-brown (10YR4/2 wet) to light-grey (10YR7/2 dry) calcareous sand containing carbonate clods and sediment aggregates, as well as land snails and rootlets providing a non-cultural minor organic component (Johnston 1996). Soil $\mathrm{pH}$ values varied from 8 (field), a highly favourable environment for the preservation of bone, to 10 (lab), which is less favourable (Reitz and Wing 2008:140141). Detailed analysis revealed that the sand was medium to fine grained (Wentworth 1933), and composed of $45 \%$ quartzite, $40 \%$ carbonate and $15 \%$ quartz. Negative skewness in the particle size distribution, grain shape and surface texture, as well as the moderate to well-sorted nature of the deposit, indicated that this was an aeolian deposit originating from beach sands (Johnston 1996). Below the midden, the sediment appeared virtually identical in the field, although slightly darker (10YR3/2).

Finally, the fact that the loose surface shell appeared to be present only in a small area directly over in situ deposits suggests that the top of the midden was only exposed a short time before the investigations occurred and that not much had been lost to wind action (i.e. no downwind surface trail of smaller items was present).

\section{Marine shellfish}

The Minimum Number of Individuals (MNI) identified to species in SM A comprised 650 


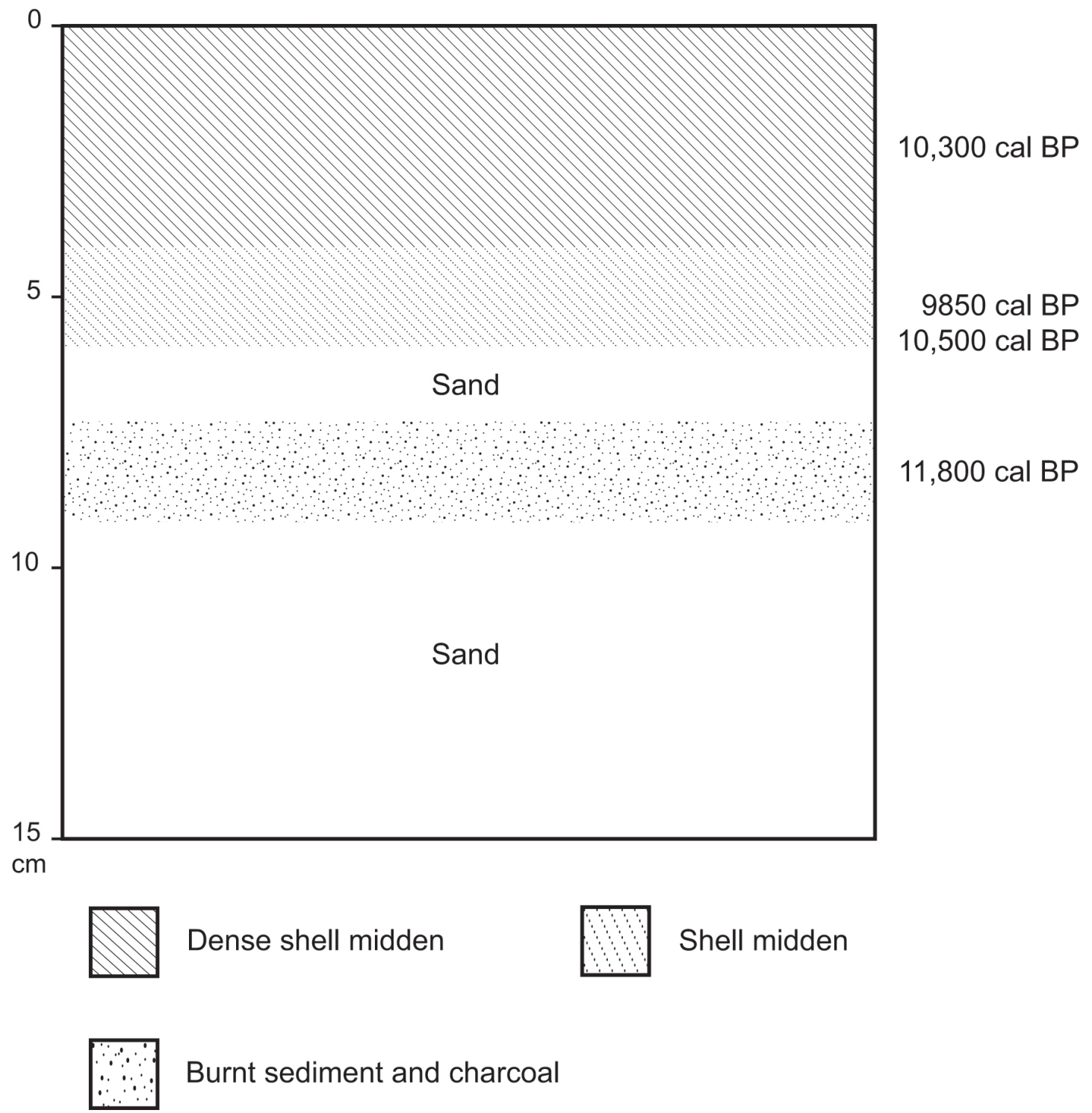

Figure 6. Shell Midden A northeast corner stratigraphy.

individuals from eight taxa of marine mollusc identified in more than $7.5 \mathrm{~kg}$ of shell recovered (Tables 3-5). The most common shellfish is Turbo undulata, at just under 70\% of the total MNI, with Cellana tramoserica contributing 18\%, Austrocochlea concemerata 9\%, and five other taxa each representing $1 \%$ or less (Table 5).

\section{Radiocarbon dating}

Four radiocarbon age determinations are pertinent to the dating of SM A, three of them on Turbo undulata shell from the midden itself, and one on wood charcoal located below the midden. Initially, one shell sample from XU 1 yielded an age determination of ca. 10,300 cal BP (Beta-93569) and another from XU 2 dated to ca. 9850 cal BP (Beta-96584) (Table 6). The determination for XU 1 was slightly older than that from XU 2, although they overlap at two standard deviations. A second shell determination was run for XU 2, ca. 10,500 cal BP (UB4369), with the resulting date older than both of the previous determinations and in sequence (Figure 7). 
A further determination on wood charcoal from the charcoal-rich layer underlying the midden deposit yielded a terminal-Pleistocene radiocarbon age determination of ca.11,800 cal BP (UB-4370), indicating a distinct occupation horizon pre-dating midden formation (Table $6)$.

\section{Other excavations and investigations}

Following excavation of SM A, with its evident in situ midden deposits, test pits were excavated at six other surface shell scatters (see Table 7). The purpose of these small-scale excavations was to evaluate whether intact midden deposits were also present, to characterise the nature of any midden layers and to obtain samples of shell and other materials for identification and dating. Similar excavation and recording methods to those employed at SM A were used on these smaller test pits.

\section{Shell Midden B}

SM B is located in a flat, nearly vegetation-free expanse of dark grey, very consolidated sandy loam, located $140 \mathrm{~m}$ to the east of Shell Midden A (Figure 2). Turbo undulata shell and a flint flake appeared to be eroding out of sandy loam palaeosol in an area measuring $7.0 \mathrm{~m}$ east-west by $6.1 \mathrm{~m}$ north-south.

SM B was tested with a single $25 \mathrm{~cm}$ square placed in the approximate centre of the exposed midden in an area of high surface shell density. Almost all shell was concentrated in the uppermost $3 \mathrm{~cm}$ of the first XU, although a small amount extended to a maximum depth of $7 \mathrm{~cm}$ in the second XU.

Two species were identified in the $70 \mathrm{~g}$ of shell recovered (Tables 3, 4). Turbo undulata

Table 3. Finds by weight $(g)$ for Cape Duquesne investigations.

\begin{tabular}{|c|c|c|c|c|c|c|}
\hline Агеа & Excavation Unit & Flaked stone & Shell & Bone & Charcoal & ochre \\
\hline SM A & surface & & 816.49 & & & \\
\hline SM A & 1 & 1.03 & 7414.81 & & 41.54 & \\
\hline SM A & 2 & & 122.83 & & 64.24 & \\
\hline SM A & 3 & & 3.24 & & 4.54 & \\
\hline SM B & 1 & & 60.30 & & 2.91 & \\
\hline SM B & 2 & & 9.57 & & 13.82 & \\
\hline SM D & 1 & & 199.28 & & 0.01 & \\
\hline SM E & surface & & 271.51 & & & \\
\hline SM E & 1 & & 60.42 & & 0.20 & \\
\hline SM E, F 50 & surface & & 65.70 & & & \\
\hline SM F & 1 & & 1030.94 & 0.09 & 3.39 & \\
\hline SM F & 2 & & 17.68 & & 0.53 & \\
\hline SM G & surface & & 61.05 & & & \\
\hline SM G & 1 & & 126.49 & & 0.80 & \\
\hline SM G & 2 & & 5.30 & & 6.70 & \\
\hline SM G & 3 & & 0.04 & & 0.25 & \\
\hline SM I & surface & 0.75 & 74.90 & & & \\
\hline SM J & 1 & & 11.56 & & 0.10 & 2.15 \\
\hline SM J & 2 & & 1.90 & & 0.80 & 0.10 \\
\hline SM J & 3 & & 0.05 & & 0.05 & \\
\hline Sub Total & surface & 0.75 & 1289.65 & & & \\
\hline Sub Total & excavated & 1.03 & 9064.41 & 0.09 & 139.88 & 2.25 \\
\hline Totals & & 1.78 & 10354.06 & 0.09 & 139.88 & 2.25 \\
\hline
\end{tabular}


Table 4. Shellfish taxa weight $(g)$ distribution by excavated shell midden.

\begin{tabular}{|c|c|c|c|c|c|c|c|c|c|c|c|c|}
\hline స్ㅠㅇ & 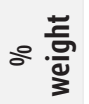 & $\stackrel{m}{\underset{\sigma}{\sigma}}$ & $\begin{array}{l}\stackrel{\circ}{\dot{d}} \\
\text {. }\end{array}$ & 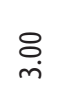 & $\stackrel{+}{\stackrel{N}{*}}$ & ô. & $\stackrel{\text { ga }}{-}$ & $\underset{\sim}{\mathbb{J}}$ & $\underset{\widetilde{O}}{\tilde{O}}$ & $\stackrel{\circ}{\circ}$ & Ő & $\bar{o}_{0}$ \\
\hline $\begin{array}{l}\text { 푱 } \\
\text { : }\end{array}$ & (3) & 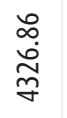 & $\begin{array}{l}\hat{a} \\
\hat{\alpha} \\
\underline{6}\end{array}$ & 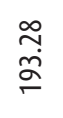 & $\underset{\Xi}{\stackrel{I}{I}}$ & $\stackrel{0}{2}$ & 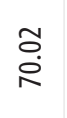 & 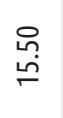 & $\underset{\dot{J}}{\stackrel{N}{\sim}}$ & 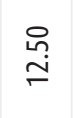 & $\stackrel{\bar{\sigma}}{\circ}$ & ô. \\
\hline & $\therefore$ & & & & & 옹 & & & & & & \\
\hline$\Sigma$ & (3) & & & & & $\underset{\substack{m \\
m}}{n}$ & & & & & & \\
\hline & $\therefore$ & $\begin{array}{l}\stackrel{\circ}{0} \\
\stackrel{0}{\circ}\end{array}$ & & & & & & & & & & \\
\hline$\sum_{n}^{0}$ & (3) & $\begin{array}{l}\underset{\Xi}{\Xi} \\
\underset{\beth}{\beth}\end{array}$ & & & & & & & & & & \\
\hline & $\therefore$ & 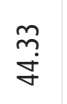 & $\begin{array}{l}\stackrel{\infty}{\stackrel{\gamma}{q}} \\
\stackrel{q}{q}\end{array}$ & & $\hat{\grave{i}}$ & $\stackrel{\widetilde{\sigma}}{0}$ & ఏ్ & & & & & \\
\hline$\sum_{n}$ & (ㅇ) & 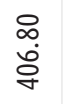 & $\begin{array}{l}\stackrel{\infty}{\circ} \\
\stackrel{\Im}{\forall}\end{array}$ & & 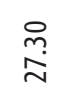 & $\underset{\widetilde{O}}{\mathbb{S}}$ & $\stackrel{\sim}{\stackrel{్}{\sigma}}$ & & & & & \\
\hline & $\therefore$ & $\begin{array}{l}\infty \\
\stackrel{0}{0} \\
\stackrel{0}{0}\end{array}$ & 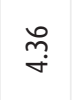 & & & $\underset{0}{\mathbb{O}}$ & & 离 & & & & \\
\hline$\sum_{n}$ & (0) & 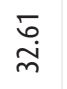 & 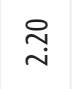 & & & $\underset{0}{\sigma}$ & & $\begin{array}{l}\text { 오 } \\
\text { مh }\end{array}$ & & & & \\
\hline & $\stackrel{\circ}{\circ}$ & $\stackrel{\infty}{\stackrel{\infty}{\sim}}$ & & $\underset{\infty}{\underset{\infty}{\alpha}}$ & & & & & & & & \\
\hline$\sum_{n}^{0}$ & (0) & 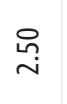 & & 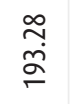 & & & & & & & & \\
\hline & 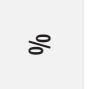 & $\begin{array}{l}\text { aे. } \\
\dot{a}\end{array}$ & & & & $\underset{\substack{\infty \\
\infty}}{\bar{\alpha}}$ & & & & & & \\
\hline$\sum_{n}^{\infty}$ & (3) & 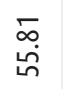 & & & & 号 & & & & & & \\
\hline & $\therefore$ & 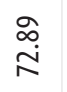 & $\underset{d}{\stackrel{J}{\sim}}$ & & $\stackrel{\sigma}{r}$ & & $\stackrel{m}{\circ}$ & & స్రి & $\stackrel{\stackrel{\sim}{0}}{0}$ & $\stackrel{\widetilde{o}}{0}$ & $\bar{\sigma}_{0}$ \\
\hline$\sum_{n}^{\infty}$ & (3) & $\begin{array}{l}\frac{}{\grave{c}} \\
\stackrel{\rho}{\circ}\end{array}$ & $\begin{array}{l}a \\
\stackrel{a}{\sim} \\
\stackrel{0}{a}\end{array}$ & & 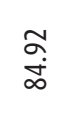 & & $\underset{b}{\stackrel{N}{6}}$ & & $\underset{\sim}{\stackrel{\sim}{\sim}}$ & $\stackrel{\stackrel{\leftrightarrow}{\sim}}{\underset{\sim}{n}}$ & $\underset{\Gamma}{\sigma}$ & oे. \\
\hline 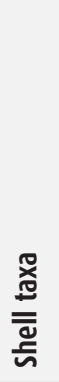 & & 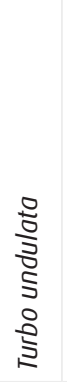 & 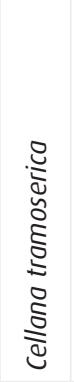 & 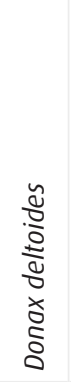 & 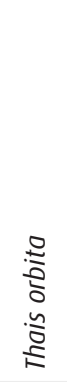 & 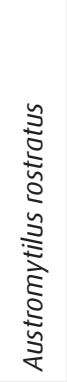 & $\begin{array}{l}\frac{0}{0} \\
\frac{0}{0} \\
\frac{0}{0} \\
\frac{\pi}{2} \\
\text { 음 }\end{array}$ & 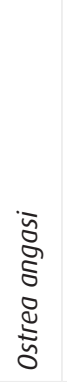 & 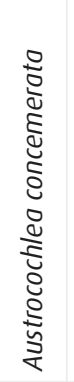 & 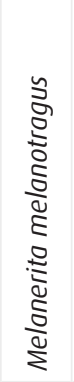 & 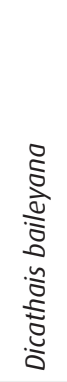 & 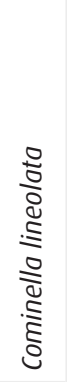 \\
\hline
\end{tabular}


Table 5. Shellfish taxa MNI percentages for each excavated shell midden.

\begin{tabular}{|c|c|c|c|c|c|c|c|c|c|c|c|c|}
\hline 要 & $\sum_{\substack{\bar{\alpha} \\
0}}^{\bar{z}}$ & $\frac{a}{\tilde{m}}$ & $\begin{array}{l}\stackrel{L}{\alpha} \\
\stackrel{\sim}{\sim}\end{array}$ & â. & $\stackrel{\mathbb{N}}{\mathbb{N}}$ & $\stackrel{m}{i}$ & $\stackrel{n}{\stackrel{n}{?}}$ & 今̊ & ڤ్ & $\stackrel{\sim}{\circ}$ & $\stackrel{\sim}{\check{0}}$ & $\stackrel{\sim}{\circ}$ \\
\hline 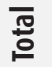 & $\sum_{\Sigma}$ & గิ & 芩 & ติ & $\stackrel{\sigma}{\sigma}$ & $\stackrel{\infty}{\sim}$ & $\stackrel{m}{n}$ & $\infty$ & in & - & - & - \\
\hline$\xi$ & $\begin{array}{l}\sum_{0}^{\bar{Z}} \\
0\end{array}$ & : & : & : & : & : & $\begin{array}{l}\text { : } \\
\text { ㅇ. }\end{array}$ & 웅 & \&. & 웅 & \&. & O̊. \\
\hline & $\overline{\bar{z}}$ & & & & & & in & & & & & \\
\hline 3 & $\begin{array}{l}\sum_{0}^{\bar{Z}} \\
0\end{array}$ & $\begin{array}{l}8 \\
\text { ¿ }\end{array}$ & : & : & : & : & : & : & 号 & : & : & : \\
\hline & $\sum_{\Sigma}^{\bar{z}}$ & 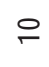 & & & & & & & & & & \\
\hline$\sum_{n}$ & $\begin{array}{l}\sum_{i} \\
0 \\
0\end{array}$ & $\begin{array}{l}\text { مी } \\
\text { సે }\end{array}$ & 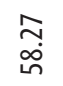 & 웅 & : & হু & $\underset{0}{\mathbb{2}}$ & $\underset{m}{\stackrel{B}{n}}$ & \&. & ¿̊. & @: & @: \\
\hline$\xi$ & $\bar{\sum}$ & ₹ & $\bar{\infty}$ & & & $F$ & - & in & & & & \\
\hline$\sum_{n}$ & $\sum_{\substack{0 \\
0}}^{\bar{j}}$ & ¿̊. & $\begin{array}{l}\stackrel{8}{0} \\
\stackrel{0}{\circ}\end{array}$ & $\stackrel{8}{8}$ & : & : & $\begin{array}{l}8 \\
0 \\
0\end{array}$ & 号 & 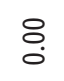 & $\begin{array}{l}8 \\
\stackrel{0}{0}\end{array}$ & $\stackrel{8}{8}$ & $\stackrel{8}{8}$ \\
\hline$\xi$ & $\bar{\Sigma}_{\Sigma}$ & $r$ & - & & & & - & & & - & & \\
\hline$\sum_{n}^{0}$ & $\sum_{\substack{0 \\
0}}^{\bar{z}}$ & 总 & @: & @: & 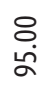 & : & 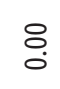 & @ọ. & @ọ. & 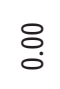 & @ọ. & @ọ. \\
\hline$\sum_{n}^{0}$ & $\bar{\Sigma}$ & - & & & $\stackrel{2}{2}$ & & & & & & & \\
\hline$\sum_{n}^{\infty}$ & 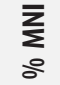 & $\begin{array}{l}\infty \\
\infty \\
\end{array}$ & : & : & : & : & 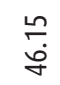 & 号 & \&. & 8 & 8 & @: \\
\hline$\sum_{n=1}^{\infty}$ & $\bar{\Sigma}$ & $r$ & & & & & 0 & & & & & \\
\hline$\sum_{n}^{\infty}$ & $\sum_{\substack{0 \\
0}}$ & $\begin{array}{l}\text { 吕 } \\
\text { ô. }\end{array}$ & 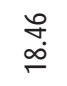 & $\stackrel{\infty}{\circ}$ & : & $\stackrel{\infty}{\stackrel{\infty}{\leftarrow}}$ & 8 & ${ }_{0}^{\circ}$ & 令 & 잉 & $\stackrel{\stackrel{n}{\circ}}{\circ}$ & $\stackrel{n}{\circ}$ \\
\hline$\sum_{n}$ & $\bar{\sum}$ & 学 & తి & 음 & & $r$ & & $m$ & in & & - & - \\
\hline 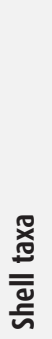 & & 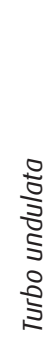 & 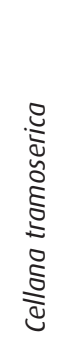 & 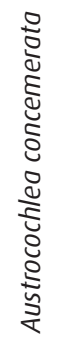 & 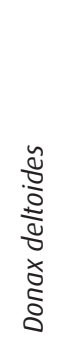 & 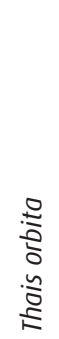 & 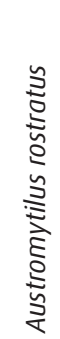 & $\begin{array}{l}\frac{0}{0} \\
\frac{0}{\bar{L}} \\
\frac{0}{0} \\
\frac{0}{2} \\
\frac{2}{0}\end{array}$ & 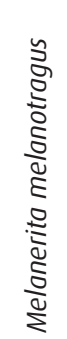 & $\begin{array}{l}\bar{s} \\
\text { sे } \\
\text { Dे } \\
\text { s̀ }\end{array}$ & 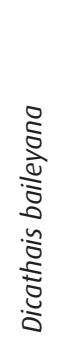 & 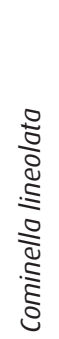 \\
\hline
\end{tabular}


Table 6. Calibrated radiocarbon age determinations from the Cape Duquesne Aboriginal landscape investigations.

宛

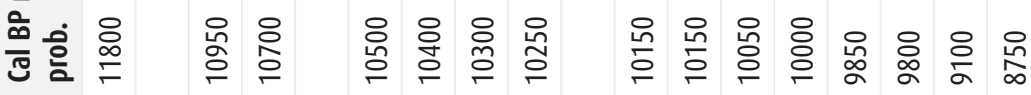

产

ตे

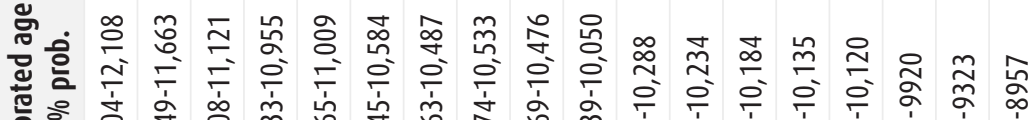

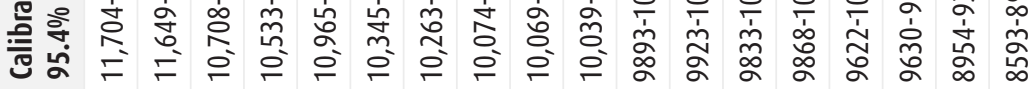

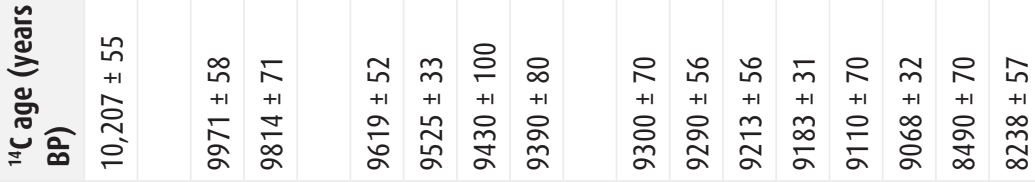

:

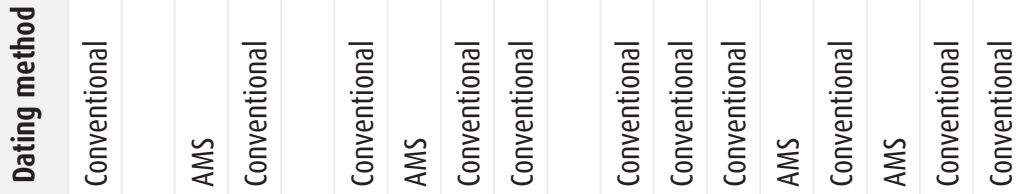

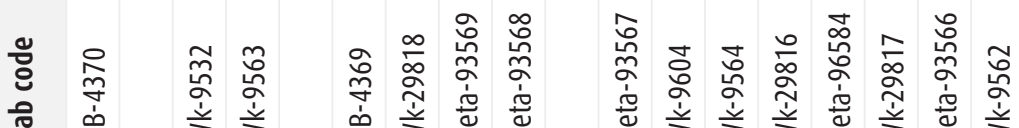

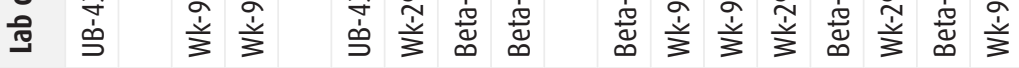

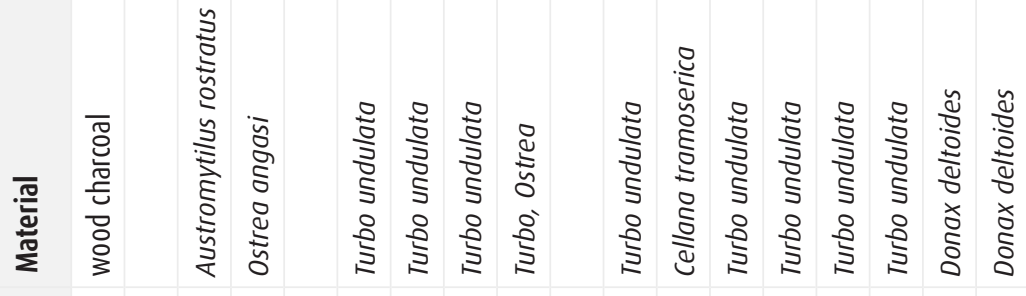

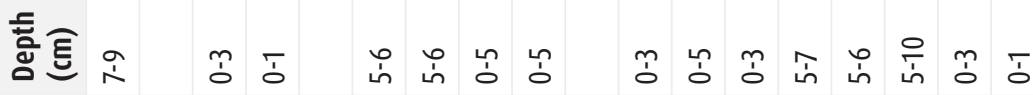

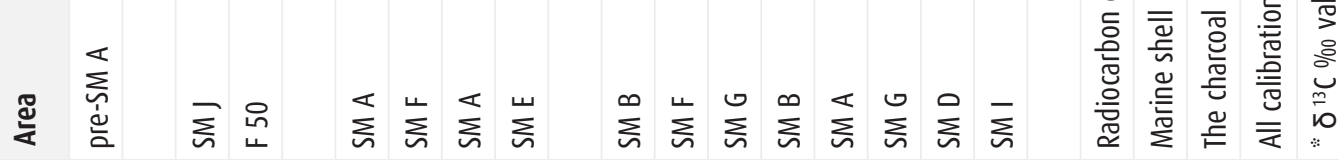




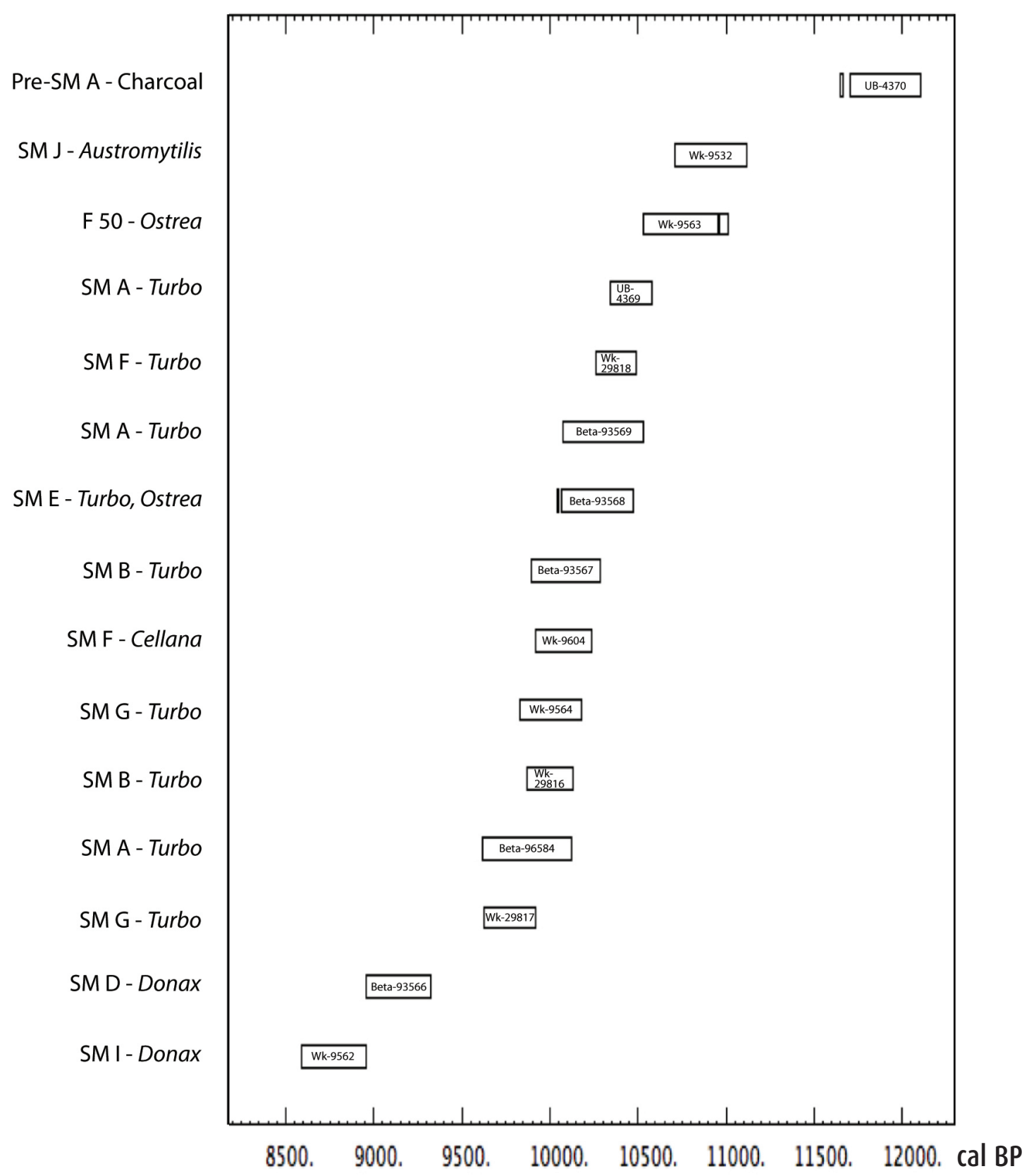

Figure 7. Cape Duquesne Aboriginal landscape radiocarbon age determinations arranged in chronological order (see Table 6 for details of age determinations). Dates are presented as bars spanning the two sigma range.

again dominated the small assemblage, at $54 \%$ of the MNI, with another rock-platform species, Austromytilus rostratus, contributing 46\% (Table 5).

A sample of Turbo undulata fragments from XU 1 was radiocarbon dated to ca. 10,150 cal BP (Beta-93567) and another on a Turbo undulata shell from XU 2 yielded an AMS determination of ca. 10,000 cal BP (Wk-29816) (Table 6, Figure 7). The samples are statistically the same age at the $95 \%$ level (T statistic) (Stuiver et al. 2011).

\section{Shell Midden D}

$\mathrm{SM} D$ is located in the south-central portion of the landscape, in a flat, sparsely vegetated area of exposed dark grey palaeosol some $50 \mathrm{~m}$ from the cliff edge (Figure 2). Flint artefacts and Donax deltoides, Cellana tramoserica, Turbo undulata and Polyplacophora shells were sitting on the surface, with some of the Donax deltoides appearing to be in situ and eroding out of the 
sediment over an expanse measuring $13.6 \mathrm{~m}$ east-west and $8.9 \mathrm{~m}$ north-south within a much larger area of the exposed dark-grey sediment.

SM D was tested with a $25 \mathrm{~cm}$ square placed in the centre of the exposed deposits in a surface shell concentration. Excavation of a single $5 \mathrm{~cm} \mathrm{XU}$ in dark-grey, consolidated sandy loam revealed that dense in situ midden deposits extended from the surface to $2-3 \mathrm{~cm}$, with a sharply defined termination.

The SM D assemblage totals $199 \mathrm{~g}$ of shell, with a trace amount of charcoal (Table 3). Donax deltoides comprises $95 \%$ of the MNI, with minor representation by Turbo undulata (5\%) (Table 5). A sample of whole Donax deltoides shells was radiocarbon dated to ca. $9100 \mathrm{cal}$ BP (Beta-93566) (Table 6, Figure 7).

\section{Shell Midden E}

Ancient sediments up to $1 \mathrm{~m}$ deep are exposed around the periphery of a large blowout towards the northeastern periphery of the landscape. Cultural material comprising SM E was exposed in section on the steep-edged eastern side of the blowout and on the surface beyond the blowout (Figure 2). In situ items in section and partially exposed on the eroding surface (not the blowout) included shell, notably Ostrea angasi, flint artefacts including a flake core, and charcoal, as well as a hearth feature (Feature 50, discussed below). At more than $750 \mathrm{~m}^{2}$, SM E is the largest midden on the landscape. ${ }^{1}$

A $25 \mathrm{~cm}$ square test pit was placed on the eastern edge of the eroded area where in situ shell, charcoal and flint artefacts were observed both in section and on the surface. Time constraints did not allow the excavation of more than one $\mathrm{XU}$, which revealed a moderately dense midden to at least $6 \mathrm{~cm}$ depth (supported by material visible in the eroded section to a similar depth). Excavation was very difficult, especially within the first few centimetres, due to the sediments being cemented with calcium carbonate. Beneath this crust was a consolidated light-grey sandy loam.

The excavated sample of $60 \mathrm{~g}$ was dominated by Turbo undulata, which comprised $70 \%$ of the MNI (Tables 3-5). Three other species, Cellana tramoserica, Austromytilus rostratus and Ostrea angasi, were each represented by $10 \%$ of the MNI. A sample of Ostrea and Turbo undulata shell from the excavation provided a radiocarbon age determination of ca. 10,250 cal BP (Beta93568) (Table 6, Figure 7).

\section{Feature 50}

Feature 50 (F 50) is located 10 m northeast of the blowout on SM E. F 50 was a cluster of burnt calcarenite cobbles measuring $4.6 \mathrm{~m}$ east-west by $4.2 \mathrm{~m}$ north-south, some in situ and some simply resting on the greyish brown, compact sandy loam surface, the surrounding sediments having been removed by wind action (Figures 2,8). These hearthstones are the only ones observed in situ in early-Holocene sediments on the Cape Duquesne landscape. Several Ostrea angasi shells were observed among the hearthstones, including two in situ shells, each approximately $50 \%$ exposed on the surface. One in situ Ostrea shell was removed for radiocarbon dating, providing a determination of ca. 10,700 cal BP (Wk-9563) (Table 6, Figure 7).

\section{Shell Midden F}

Located on the eastern side of the landscape, $\mathrm{SM} \mathrm{F}$ is a largely unvegetated surface exposure of eroding shells, measuring $18.8 \mathrm{~m}$ east-west by $14.6 \mathrm{~m}$ north-south (Figure 2). A single pass

1 Detailed examination of the area around Shell Midden E, Shell Midden H and Feature 50 during contour mapping operations revealed that the distribution of surface cultural material showed no gaps between Shell Middens $\mathrm{E}$ and $\mathrm{H}$. As a result, SM H is now incorporated within SM E and is no longer regarded as a discrete midden. Feature 50 is within the boundaries of SM E and is now regarded as part of that midden, although it still retains its designation as a feature. 


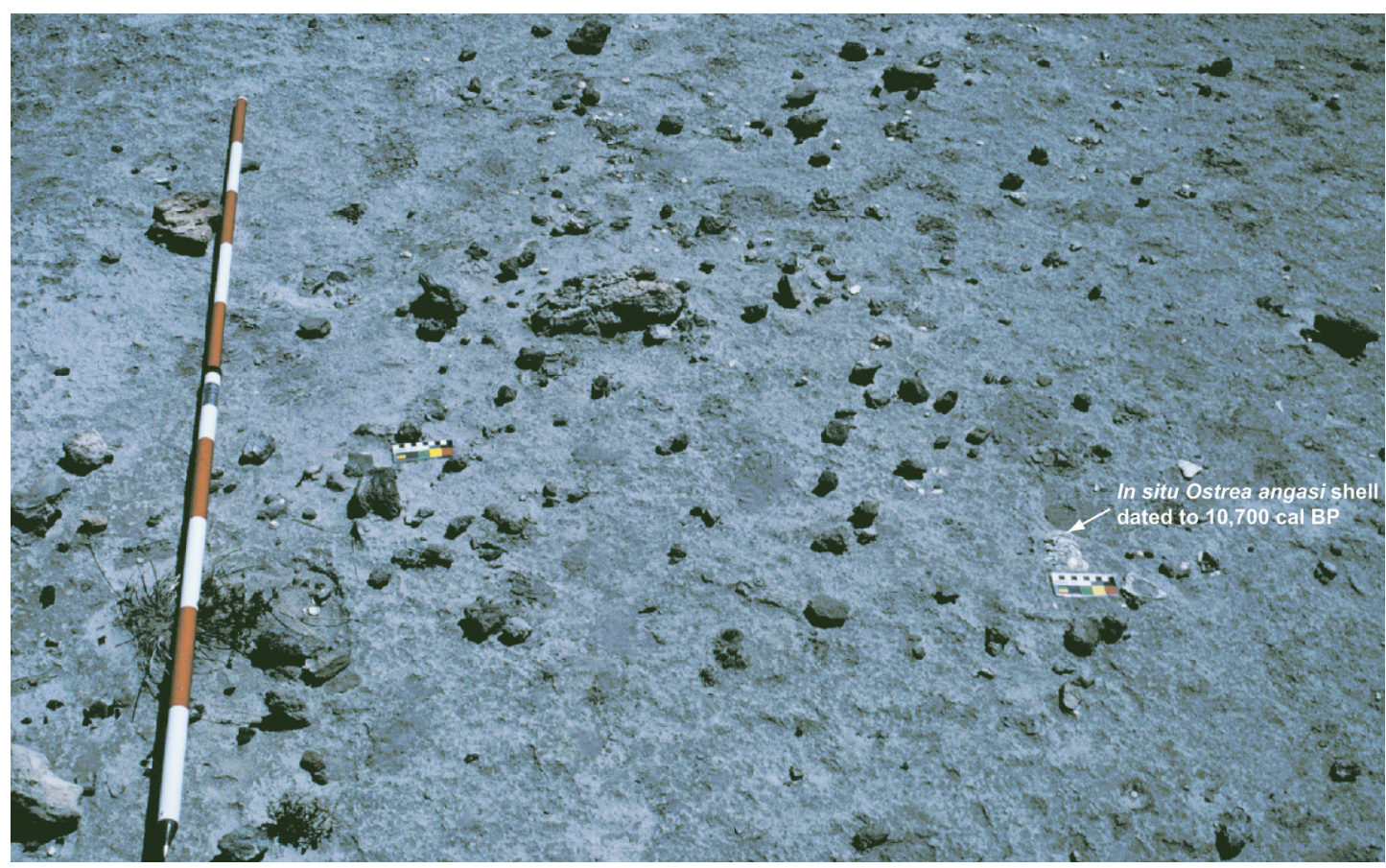

Figure 8. Feature 50 at Shell Midden E, showing burnt calcarenite rocks and Ostrea angasi shell in compact sandy loam palaeosol. Ranging pole bars are $20 \mathrm{~cm}$ long; small scales are $10 \mathrm{~cm}$ long.

by plough by the land management authority for the purpose of creating furrows for replanting to stabilise the area exposed significant densities of Cellana tramoserica, Turbo undulata, Thais orbita and Donax deltoides shell.

A $40 \mathrm{~cm}$ square was placed over an average surface expression of Cellana tramoserica and Turbo undulata shell located between furrows (Figure 9:top). The loose shells, some nearly whole, some fragmented, were swept up and bagged before the excavation of XU 1.

Once the excavation started, Cellana tramoserica and Turbo undulata shells were found to be very dense, comparable to SM A and SM D (Figure 9:bottom). A few small chunks of dubiously cultural charcoal were found near the surface in the northwest corner and also deeper in the southwest. Pointing trowels and dental picks were used to remove the compact sediment from around the tightly packed shells so they could be removed without damaging them. The first XU was excavated to the bottom of the dense concentration of shell, at $5 \mathrm{~cm}$ below the surface.

XU 2 was excavated to establish the depth of sterile deposits. Only small fragments of shell were recovered and they clearly came from the upper $1 \mathrm{~cm}$ of the $5 \mathrm{~cm}$ deep XU. Small pieces of charcoal were found throughout the XU.

The surface consisted of a greyish-brown (10 YR 5/2) fine sand with almost no vegetation cover. The sediment in both excavated XUs was identical to that on the surface, except it was lightly consolidated in comparison to the very consolidated surface crust.

SM F is the only midden dominated by Cellana tramoserica; out of $1049 \mathrm{~g}$ of shell, Cellana tramoserica comprised 58\% of the total MNI, Turbo undulata 29\%, Thais orbita 7\%, Polyplacophora 3\% and Austromytilus rostratus <1\% (Tables 3-5).

A sample of whole Cellana tramoserica shells from XU 1 was submitted for radiocarbon dating, yielding an age estimate of ca. 10,150 cal BP (Wk-9604) (Table 6, Figure 7). An AMS age determination of ca. 10,400 cal BP (Wk-29818) was obtained on a Turbo undulata shell from XU 2. The samples are significantly different at the 95\% level (T statistic) (Stuiver et al. 2011). 

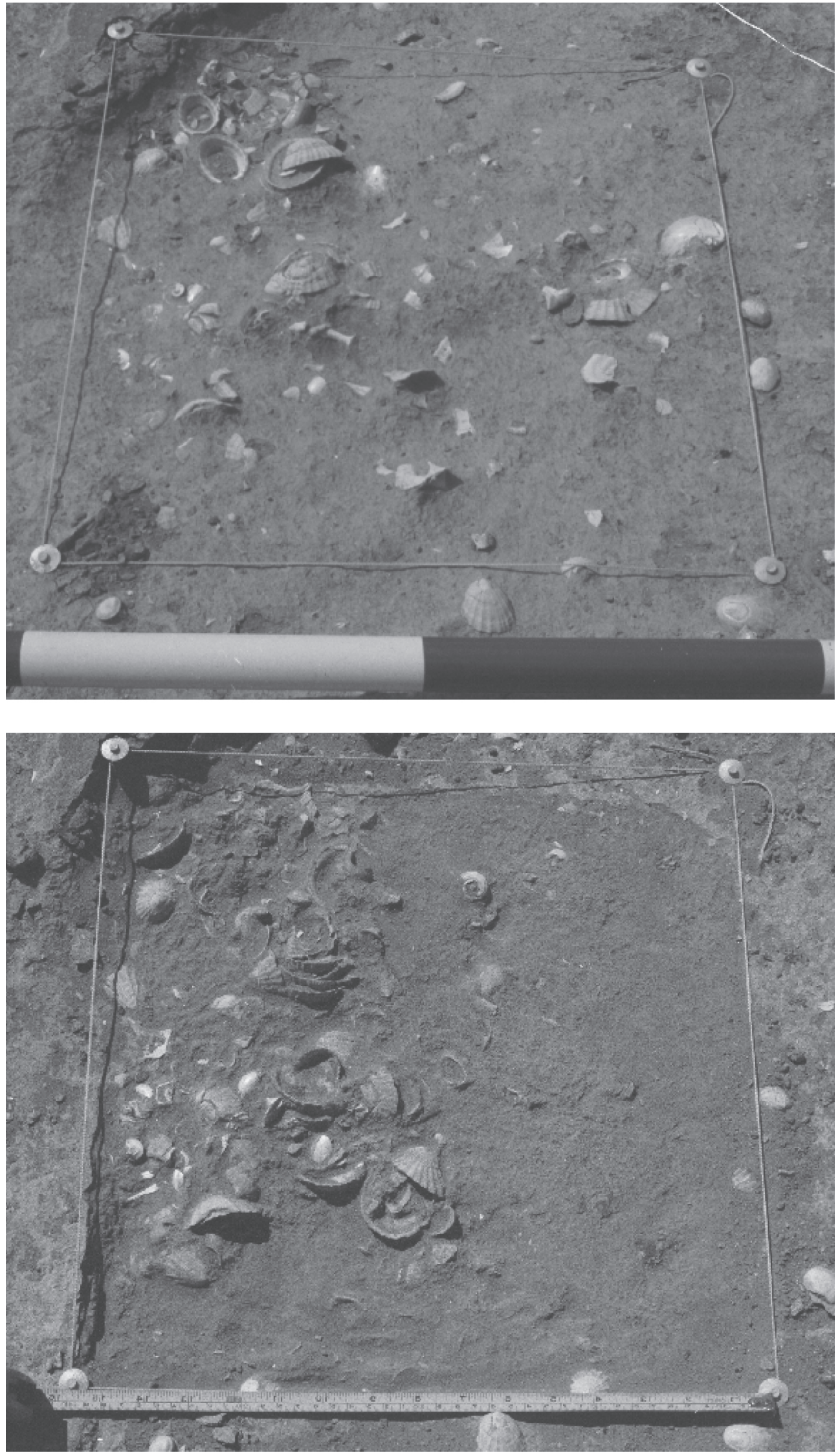

Figure 9. Shell Midden F, Square 1: (top) pre-excavation view showing midden material on surface of palaeosol; (bottom) initial stage of excavation following removal of loose surface material, exposing dense in situ shell. Ranging pole bars are $20 \mathrm{~cm}$ long. 


\section{Shell Midden $G$}

SM G, located in the northeast of the landscape, was eroded by wind action and largely devoid of vegetation (Figure 2). Flint artefacts, Turbo undulata, Cellana tramoserica and Donax deltoides shells and fragmented animal bone were exposed on the surface over an area approximately $16 \mathrm{~m}$ in diameter. SM G was investigated with a $40 \mathrm{~cm}$ square test pit excavated in an area of average surface shell density. Surface sediments were a loose, light-grey (10YR 7/1) sand. Sediment in XUs 1 and 2 consisted of lightly consolidated, light-grey (10YR 5/2), fine sand with few rootlets. The only change in the XU 3 sediment was the addition of small calcarenite pebbles to the sand.

Turbo undulata shell was concentrated in the upper few centimetres of the first XU, with very little in the two XUs excavated below that (Table 3). A sample of $132 \mathrm{~g}$ of shell was recovered, with Turbo undulata comprising 100\% of the shellfish MNI (Tables 3-5).

Large Turbo undulata fragments from XU 1 provided a radiocarbon determination of ca. 10,050 cal BP (Wk-9564) (Table 6, Figure 7). A single Turbo operculum from XU 2 yielded an AMS age determination of ca. 9800 cal BP (Wk-29817). The samples are significantly different at the $95 \%$ level (T statistic) (Stuiver et al. 2011), although they overlap at 2 s.d.

\section{Shell Midden I}

SM I, located at the eastern end of the landscape, is approximately $3.2 \mathrm{~m}$ in diameter and consists of a cluster of Donax deltoides shell and a few flint artefacts on the surface (Figure 2). No excavations were undertaken at this midden, but a Donax deltoides sample consisting of some partially exposed, in situ shells, but mostly loose surface shells, was collected from an approximately $1 \mathrm{~m}$ diameter area (Table 3). A radiocarbon age determination of ca. $8750 \mathrm{cal}$ BP (Wk-9562) was obtained on whole Donax deltoides shell (Table 6, Figure 7).

\section{Shell Midden J}

Shell Midden J, located in the south-central part of the landscape, measures $13.5 \mathrm{~m}$ northsouth, by $9.1 \mathrm{~m}$ east-west on a much larger exposure of sandy loam sediment almost devoid of vegetation cover and containing numerous surface cracks (Figure 2). SM J had one dense in situ exposure of mainly Turbo undulata shell covering ca. $5 \mathrm{~m}^{2}$, with scattered Turbo undulata, Cellana tramoserica, Donax deltoides and Austromytilus rostratus shell evident over a larger area. Notably, two Austromytilus rostratus shells were present on the surface on the southern edge of the midden. As the other middens had only yielded a small amount of shell of this species, it was decided to recover some from this area, both to obtain basic information on subsistence and to provide material for radiocarbon dating. A $50 \times 50 \mathrm{~cm}$ square was laid out on the southern edge of the midden to include the partially exposed Austromytilus rostratus shells.

The Austromytilus rostratus shells, which were in a crumbly condition and only held together by the highly consolidated sediment, fell apart as they were gently exposed with pointing trowels. Excavation generally proved to be very difficult and progressed very slowly despite the use of highly sharpened tools. Very little additional shell was found in the first XU, and what was there was fragmentary and friable. Almost no shell was apparent near the bottom of the level, the last $1 \mathrm{~cm}$ of which was completed by careful shovel shaving. Hand picks were cautiously used to excavate the second, $5 \mathrm{~cm}$-thick XU. Very little shell was found, and what was there was fragmented. A third XU was excavated only in the southeast quadrant (a $25 \mathrm{~cm}$ square). Only one tiny shell fragment and a few pieces of charcoal were present (Table 3).

There was no vegetation on the surface of the square, which was a greyish-brown (10 YR 5/2), very consolidated sandy loam. Sediment in XUs 1 and 2 is a greyish-brown (10 YR 3/2), very consolidated sandy loam. Cracks visible on the surface were still present down to XU 2 . Sediment in XU 3 is a dark-brown (10 YR 3/3), consolidated sandy loam with small, rounded, 
calcarenite pebbles.

Very little shell was recovered from the test excavation in SM J, totalling only $13 \mathrm{~g}$ (Table 3). Austromytilus rostratus was the only species represented, with a MNI of 5 (Table 5). A trace of charcoal was present in each of the excavated XUs and a few grams of red ochre were present in XU 1, with a tiny amount in XU 2 (Table 3).

An AMS radiocarbon age determination of ca. 10,950 cal BP (Wk-9532) was obtained on Austromytilus rostratus shell from XU 1 (Table 6). This is the earliest age determination on shell from the landscape (Figure 7).

\section{Sediment discussion}

SM A sediment is similar to the late-Pleistocene-to-Holocene Discovery Bay Sand (Gibbons and Downes 1964), Undifferentiated Calcareous Sands (Land Conservation Council 1981), Discovery Bay and Bridgewater Sands (Cupper et al. 2003) and Poorly Consolidated Calcareous Sand (Rosengren 2001a) previously described for the region. It is clearly not a Pleistocene terra rossa or rendzina palaeosol, typically associated with the Bridgewater Group in this region. The location of the excavation, on a large sand dune, well above contact with the underlying Bridgewater Group calcarenite, further reinforces this interpretation.

In fact, the sediment in SM A closely matches Discovery Bay beach and dune sediments that also consist of grey-brown, fine-medium calcareous sand, with a virtually identical mean grain size (Buckley 1992:18, Table 2). In addition, there is a highly similar carbonate content to samples from Descartes Bay (Buckley 1992: Appendix 2). The data strongly indicate that the SM A sediment and the Discovery Bay-Descartes Bay beach and dune deposits mainly derive from the same calcareous continental shelf deposits exposed from the LGM (ca. 20,000 cal BP) well into the Holocene (Land Conservation Council 1981:14; Short 1988:121; Buckley 1992:20; Bird 1993:25; Rosengren 2001a:213-215; Sloss et al. 2007).

None of the other excavations had sediment analysis undertaken as with SM A, but the field observations from SM J are sufficient to indicate that this is a substantially different sediment. Firstly, SM J is present in a shallow, very consolidated, greyish-brown sediment, with surface cracks evident, directly overlying calcarenite. Excavation was very difficult at this site due to the very consolidated nature of the soil, which had a sandy loam texture and contained small calcarenite pebbles. This sediment does not compare well with SM A or the nearby beach and dune sands, and is rather more like the Bridgewater Group palaeosols that commonly cap calcarenite. It is especially similar to the Bridgewater Sandy Loam, a rendzina soil (Gibbons and Downes 1964: Appendix 1). Radiocarbon dating of a shell sample from the top of this deposit yielded the oldest shell determination for the site, an early-Holocene date of ca. 10,950 cal BP, further supporting this interpretation. The matrix of F50 was a similar dark-grey, very consolidated sandy loam, overlying calcarenite, a shell from which produced a radiocarbon age determination of ca. 10,700 cal BP.

Of the other shell middens, the sediment textures, $\mathrm{pH}$ values, consolidation and colour varied somewhere between the extremes of the loose, sandy SM A and the very consolidated sandy loam of SM J. Texture was typically finer and more compacted than SM A - varying from lightly consolidated fine sand (SM F, SM G), to consolidated sandy loam (SM B, SM D) and very consolidated sandy loam (SM E, SM J). 
Table 7. Summary of excavated early-Holocene shell midden characteristics at Cape Duquesne.

\begin{tabular}{|c|c|c|c|c|c|c|c|}
\hline 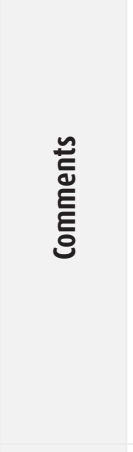 & 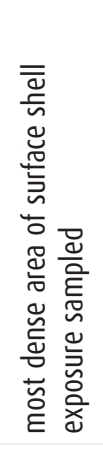 & 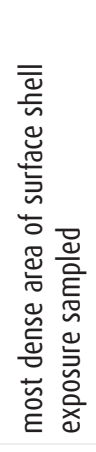 & 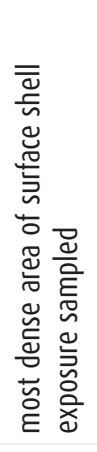 & 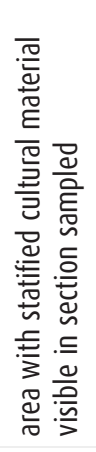 & 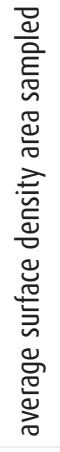 & 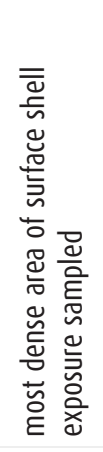 & 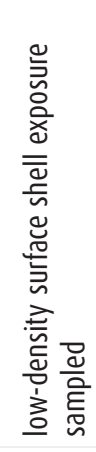 \\
\hline 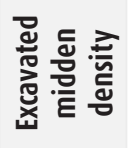 & 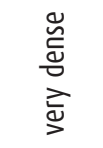 & $\begin{array}{l}\ddot{\mathscr{L}} \\
\text { Q্ }\end{array}$ & 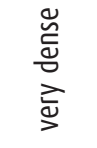 & 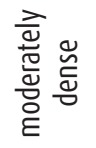 & 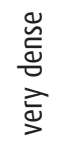 & $\begin{array}{l}\mathscr{\mathscr { E }} \\
\text { Q্ }\end{array}$ & 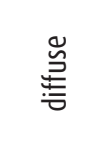 \\
\hline 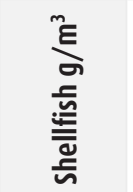 & 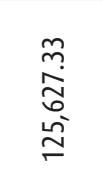 & $\begin{array}{l}8 \\
0 \\
0 \\
i \\
\text { i }\end{array}$ & 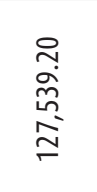 & 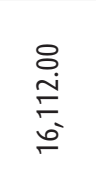 & 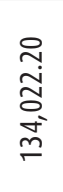 & 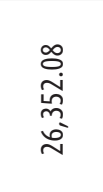 & 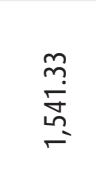 \\
\hline 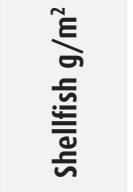 & 怘 & 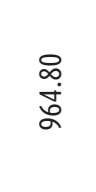 & $\begin{array}{l}\infty \\
\stackrel{\infty}{0} \\
\infty \\
\infty \\
\infty\end{array}$ & $\begin{array}{l}\text { No } \\
\text { Oڤ }\end{array}$ & $\frac{5}{5}$ & $\underset{\infty}{\stackrel{\infty}{\infty}}$ & $\begin{array}{l}\underset{J}{J} \\
\stackrel{\sigma}{ }\end{array}$ \\
\hline 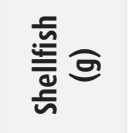 & 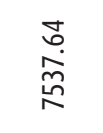 & $\begin{array}{l}\text { ồ } \\
\text { ô }\end{array}$ & 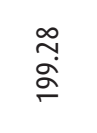 & $\begin{array}{l}\text { \&े. } \\
\text { ơ }\end{array}$ & $\begin{array}{l}\text { वू. } \\
\text { oे } \\
\text { ᄋ. }\end{array}$ & 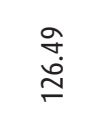 & $\stackrel{\stackrel{\circ}{\circ}}{\stackrel{n}{F}}$ \\
\hline 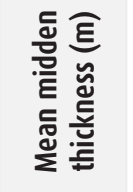 & : & $\begin{array}{l}\text { O̊. } \\
\text { O. }\end{array}$ & 㫕 & : & 号 & 弚 & $\begin{array}{l}\text { O̊. } \\
\text { O. }\end{array}$ \\
\hline 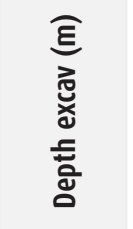 & $\stackrel{\llcorner}{\check{0}}$ & 웅 & 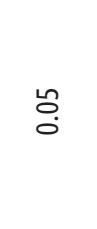 & 웅 & $\frac{}{\circ}$ & $\stackrel{\operatorname{Ln}}{\check{0}}$ & $\stackrel{\operatorname{Ln}}{\circ}$ \\
\hline 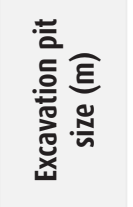 & $\begin{array}{l}\stackrel{0}{\dot{x}} \\
\stackrel{x}{\circ} \\
\stackrel{0}{-}\end{array}$ & $\begin{array}{l}\stackrel{\sim}{\sim} \\
\stackrel{x}{x} \\
\stackrel{\sim}{\sim}\end{array}$ & $\begin{array}{l}\stackrel{\sim}{\sim} \\
\stackrel{x}{\sim} \\
\stackrel{\sim}{\sim}\end{array}$ & $\begin{array}{l}\stackrel{L}{\sim} \\
\times \\
\stackrel{\sim}{\sim}\end{array}$ & $\begin{array}{l}\stackrel{q}{q} \\
\stackrel{x}{+} \\
q\end{array}$ & $\begin{array}{l}\stackrel{q}{+} \\
\stackrel{x}{+} \\
\dot{q} .\end{array}$ & 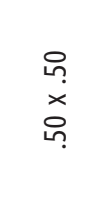 \\
\hline 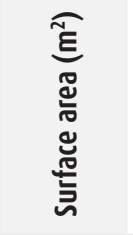 & $a$ & $\dddot{F}$ & $\bar{\beth}$ & 员 & $\underset{\sim}{\stackrel{\star}{~}}$ & $\stackrel{\text { ڤొ }}{\sim}$ & $\cong$ \\
\hline$\frac{\overline{0}}{\frac{0}{2}}$ & $\sum_{n}^{\infty}$ & $\sum_{n}^{\infty}$ & $\sum_{n}^{0}$ & $\sum_{n}^{\omega}$ & $\sum_{n}^{L}$ & $\sum_{n=1}^{0}$ & $\sum_{n}$ \\
\hline
\end{tabular}




\section{Variability in midden density}

Intact shell midden deposits were encountered in all but one of the excavations. ${ }^{2}$ There was some variability in the structure of the shell midden deposits and they ranged from diffuse through very dense. In all cases, a single shell layer was present, and these varied from tightly defined 2-3 cm thick middens (SM B, SM D, SM G) to well defined 5-6 cm thick SMs A and F, through to much less well defined deposits, such as the tested areas in SM E and SM J (Table 7). For comparative purposes, shell weight per cubic metre has been extrapolated from the testing, which reveals that SM A, SM D and SM F had the highest ratio of shell weight to excavated volume, expressed as kilograms of shell per cubic metre, at $125-134 \mathrm{~kg} / \mathrm{m}^{3}$, and these three middens are characterised as very dense (Table 7). SM B and SM G are described as dense middens, at $26-32 \mathrm{~kg} / \mathrm{m}^{3}, \mathrm{SM} \mathrm{E}$ is moderately dense, with $16 \mathrm{~kg} / \mathrm{m}^{3}$, and SM J can be considered diffuse, at $1.5 \mathrm{~kg} / \mathrm{m}^{3}$. These values are best regarded as an indicator of the range of midden densities to be found on the landscape, rather than an average density for each midden.

\section{Size and extent of middens on the landscape}

The middens had a variety of contents, including hearth features, flaked stone, charcoal, red ochre and animal bone, but with a consistent domination by marine shellfish remains. In situ midden deposit was found in patches ranging from $<10$ to $752 \mathrm{~m}^{2}$, with a total for the eight early-Holocene middens of just over $1575 \mathrm{~m}^{2}$ (Table 7). This figure should be read as a minimum because deposits were covered by overlying sediments in some cases; for example, the observed portion of SM A was only about $9 \mathrm{~m}^{2}$, yet it may well have covered an area in excess of $100 \mathrm{~m}^{2}$, but this could not be confirmed without disturbing overlying semi-stable dune deposits that were protecting the midden from wind attack. The landscape has also suffered enormously from wind erosion and every midden observed has had an unknown quantity of material removed from above the observed in situ shell, indicating the possibility that the middens covered a larger area than presently preserved. It is also a near certainty that some early-Holocene middens have eroded away entirely, but of course this is something that cannot be proven. Finally, a reasonable estimate of the extent of early-Holocene middens on this landscape, taking into consideration those entirely removed by wind erosion and those probably still covered by overlying sediment, would be to double the observed extent of midden, to 3000 $\mathrm{m}^{2}$ as a maximum figure.

\section{Midden formation}

Multiple radiocarbon age determinations are available for several middens that are each structurally different and which provide insights into midden formation. In the case of SM A, there is a dense shell concentration $4 \mathrm{~cm}$ thick, overlying $2 \mathrm{~cm}$ of less-dense shell deposit that yielded two age determinations that are statistically the same. A third determination, from the less-dense deposit, is ca. 500 years more recent than the other dates, out of sequence, and statistically different from them. A single occupational event is indicated in the midden deposit, and although the out-of-sequence date suggests later material is also present, this may be intrusive from eroded deposits overlying the stratified occupation of ca. 10,400 cal BP.

The structure of SM F is similar to SM A, with a concentration of shell in the upper 5

$2 \quad$ Shell Midden C was also tested, but is not shown on Figure 2 or discussed, because as Richards and Jordan (1996) observed: "Excavation of one spit quickly revealed that all cultural materials were only superficially embedded in the upper few millimetres of the sediment and no in situ deposits were present. The materials observed here had clearly been redeposited, having in all likelihood been moved from a location to the north down to the 'midden' by slopewash.' 
Table 8. Shellfish taxa description and ecology (after Macpherson and Gabriel 1962; Coutts 1967; Dakin 1976, 1987; Wilson and Gillett 1979, 1980; 0'Sullivan 1980; Godfrey 1984; Davey 2000; Australian Museum 2010; Beechey 2009; Barwon Bluff Marine Sanctuary 2010; NSW Fisheries 2010; Species Bank 2010).

\begin{tabular}{|c|c|c|c|c|c|c|c|c|c|c|c|}
\hline 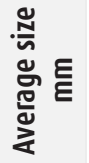 & 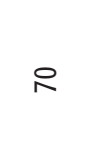 & 8 & $\stackrel{\sim}{\sim}$ & 8 & $\infty$ & P & $\stackrel{L}{\infty}$ & $\stackrel{m}{ }$ & $\stackrel{\overbrace{}}{\beth}$ & $\stackrel{L_{m}^{\prime}}{n}$ & $\stackrel{\llcorner}{\sim}$ \\
\hline 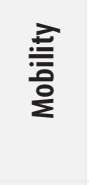 & $\begin{array}{l}\frac{\varrho}{\overline{\bar{~}}} \\
\stackrel{\circ}{E}\end{array}$ & $\begin{array}{l}\frac{\mathscr{O}}{\overline{\bar{O}}} \\
\underline{\varepsilon}\end{array}$ & $\begin{array}{l}\frac{\mathscr{O}}{\overline{\bar{O}}} \\
\underline{E}\end{array}$ & 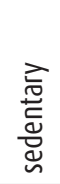 & $\frac{\mathscr{\varrho}}{\overline{\bar{~}}}$ & $\begin{array}{l}\text { त्र } \\
\text { 离 } \\
\text { 岕 }\end{array}$ & 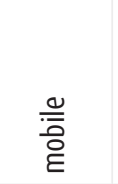 & $\begin{array}{l}\stackrel{\varrho}{\overline{\bar{~}}} \\
\stackrel{\varepsilon}{\varepsilon}\end{array}$ & 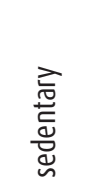 & $\begin{array}{l}\stackrel{.}{\overline{\bar{~}}} \\
\stackrel{\text { है }}{E}\end{array}$ & 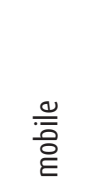 \\
\hline 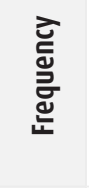 & 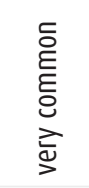 & $\begin{array}{l}\text { 䓌 } \\
\text { 蒿 } \\
\text { 言 }\end{array}$ & 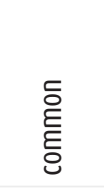 & 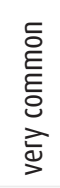 & 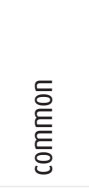 & $\begin{array}{l}\text { 䓌 } \\
\text { 咅 } \\
\text { 总 }\end{array}$ & 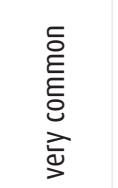 & 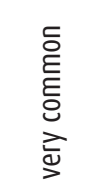 & 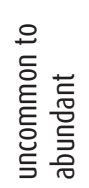 & 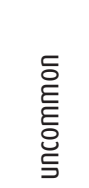 & 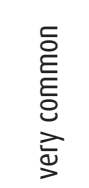 \\
\hline 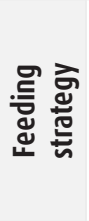 & 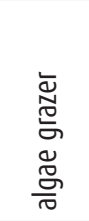 & 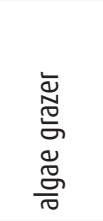 & 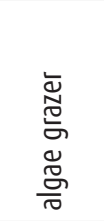 & 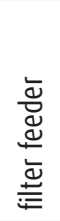 & 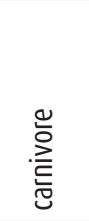 & 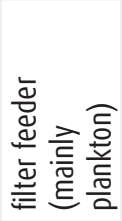 & 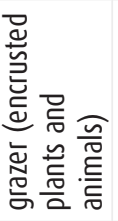 & 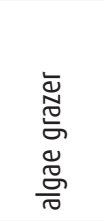 & 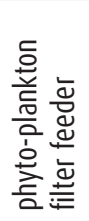 & 冚 & 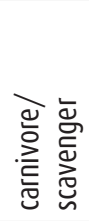 \\
\hline 总 & 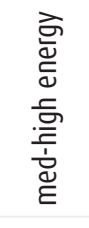 & 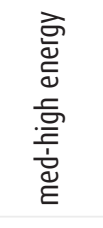 & 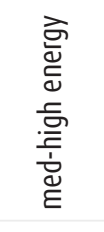 & 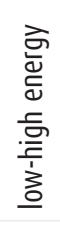 & 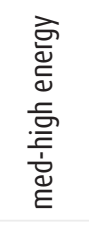 & 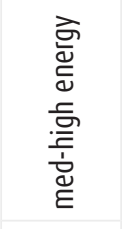 & 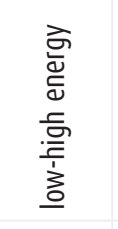 & 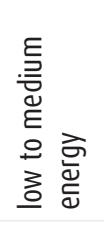 & 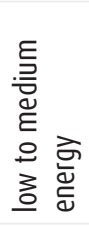 & 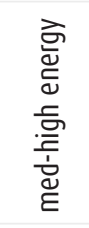 & 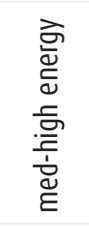 \\
\hline 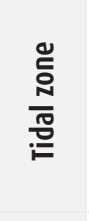 & 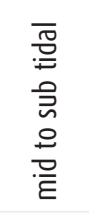 & 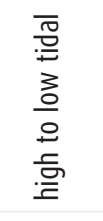 & 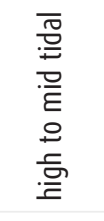 & 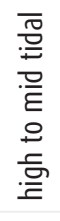 & 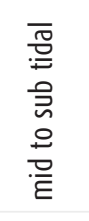 & 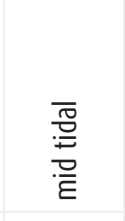 & 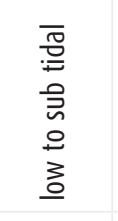 & 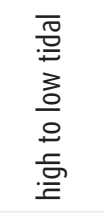 & 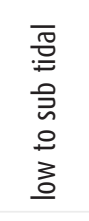 & 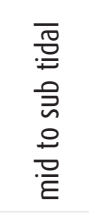 & 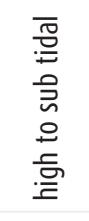 \\
\hline 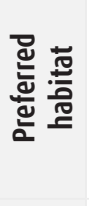 & 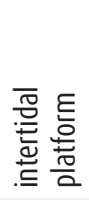 & 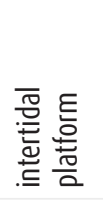 & 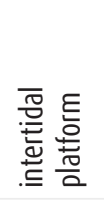 & 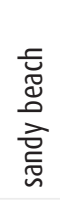 & 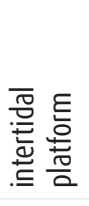 & 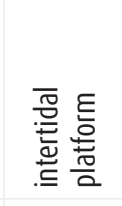 & 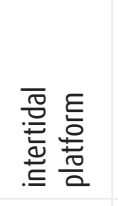 & 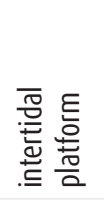 & 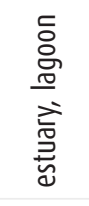 & 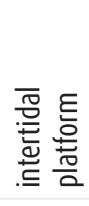 & 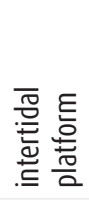 \\
\hline $\begin{array}{l}\text { 营 } \\
\text { 今 }\end{array}$ & 흥 & 흥 & 흥 & 总 & 흥 & 흥 & 흥 & 흥 & $\begin{array}{l}\overline{\overline{\bar{n}}} \\
\overline{\bar{c}} \\
\overline{\bar{n}}\end{array}$ & 흥 & 흥 \\
\hline 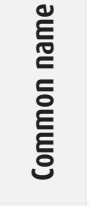 & 总 & 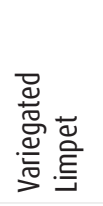 & 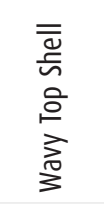 & $\bar{a}$ & $\begin{array}{l}\text { 竧 } \\
\text { 岕 } \\
\text { 品 }\end{array}$ & 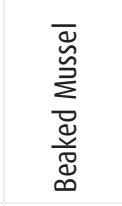 & 总 & 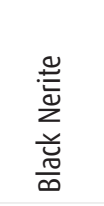 & 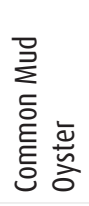 & 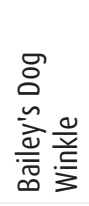 & 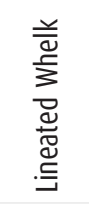 \\
\hline 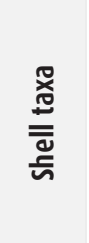 & 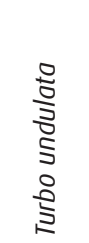 & 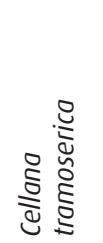 & 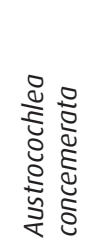 & 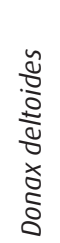 & 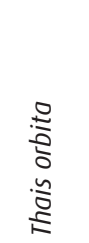 & 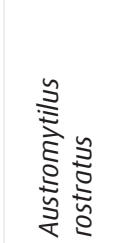 & 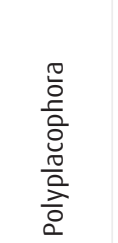 & 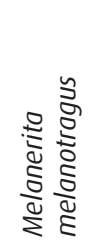 & 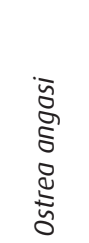 & 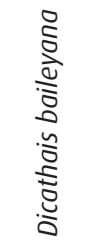 & 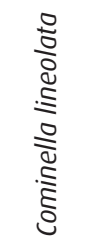 \\
\hline
\end{tabular}


$\mathrm{cm}$ and sparse shell extending only $1 \mathrm{~cm}$ below that. The age determinations from each are statistically different, a few hundred years apart, and in sequence. In this instance, repeated occupation is indicated.

SM B has a concentration of shell in the upper $3 \mathrm{~cm}$, with sparse shell below that to $7 \mathrm{~cm}$ depth, and dates from the dense and sparse shell deposits are statistically the same age. A single occupational event is indicated.

The structure of SM G is similar to SM B, with a concentration of shell in the upper $3 \mathrm{~cm}$ and sparse shell below that to $10 \mathrm{~cm}$. In this case, the age determinations from the dense and sparse deposits are statistically different, but not in sequence, with the underlying date a few hundred years more recent than the overlying one. On the other hand, there is still a 100-year overlap between the two dates at two standard deviations and the difference in median ages is only 250 years on ca. 10,000 year dates. Repeated occupation is indicated.

To summarise, these open-air middens show a strong integrity considering that they are thin and shallow deposits (around $5 \mathrm{~cm}$ in depth) that have survived for 10,000 years or longer. Treadage alone is enough to explain the minor mixing revealed by the dating in some of these deposits. Some middens represent single, short-term occupation events and others represent a few short-term occupations over a few hundred years. The general chronological signature is of repeated, short-term occupation of this landscape.

\section{Shellfish species frequency}

The majority of the 11 shellfish taxa recorded in the shell midden deposits are rock-platform species (Tables 5, 8). Turbo undulata dominates the overall excavated shellfish assemblage, at nearly $62 \%$ of the total MNI of 847 , and is the most common species in four of the seven tested middens (SMs A, B, E and G), as well as being represented in all of the other middens. It may well be the dominant species in SM J as well, because the testing there deliberately avoided the most dense in situ deposits exposed on the surface, which were strongly dominated by Turbo undulata. The next most important species in the total assemblage is Cellana tramoserica, which represents nearly $24 \%$ of the MNI. This species dominates one of the middens (SM F) and is prominent in another (SM A).

Austrococblea concemerata comprises close to $7 \%$ of the total MNI, but this species is only represented in SM A (Table 5). Thais orbita comprises just over $2 \%$ of the MNI. Sandy shore species Donax deltoides make up slightly less than $2 \%$ of the excavated MNI, although it is the dominant species in SM D and appears to be dominant at the unexcavated SM I. Austromytilus rostratus comprises just over $1.5 \%$ of the assemblage, and although it is absent in SM A, it is represented in four other middens (SM D, E, F and J). Of the five other species present in the excavated assemblage, all comprise $<1 \%$ of the total MNI, and they are mostly only present in SM A. The estuarine/muddy shore Ostrea angasi is only represented at SM E and F 50, and although its large size makes it appear prominent, there are only around five examples exposed on the surface over a very large area. Looked at another way, rock-platform species dominate six middens (SM A, B, E, F, G and J), while sandy-shore species dominate two middens (SM $\mathrm{D}$ and I).

\section{Shellfishing chronology}

The overall chronological range of shell middens on this landscape, considering the two sigma range of calibrated radiocarbon age determinations, indicates middens were deposited as late as ca. $8600 \mathrm{cal} \mathrm{BP}$ and as early as ca. $11,100 \mathrm{cal} \mathrm{BP}$, a maximum span of 2500 years (Table 6 , Figure 7). If the median probability of each calibrated date is used, the midden-related 
occupation span is 2200 years ( $8750-10,950 \mathrm{cal} \mathrm{BP})$.

There is some chronological patterning in shellfish species presence in the middens. The earliest shell dates are on Austromytilus rostratus and Ostrea angasi, from the period ca. 10,95010,700 cal BP from SM J and F 50 (Table 6). The Austromytilus rostratus and Ostrea angasi dates may indicate an early period of landscape occupation when these species were important economic contributors, but Turbo undulata is also common in deposits exposed near the dated locations.

The main period of landscape occupation is defined by eight dates on middens (SM A, B, E, F and G), with a strong focus on Turbo undulata, which range from ca. 10,500 to ca.10,000 cal BP (which may be expanded slightly to include two out-of-sequence age determinations of ca. $9800 \mathrm{cal} \mathrm{BP}$ and ca. $9850 \mathrm{cal} \mathrm{BP}$ ) (Figure 7).

Finally, there is a late-occupation pulse with a focus on Donax deltoides around $9000 \mathrm{cal}$ BP at SM D and SM I (ca. 9100-8750 cal BP).

\section{Nature and distribution of shellfish resources}

Characteristics of the shellfish species found in the middens on the Cape Duquesne landscape are provided in Table 8. The majority of species found in the middens at Cape Duquesne are adapted to high-wave energy coasts. Further, all but two species are adapted to rock substrates. All tidal zones are represented in the above species, from high tidal to sub tidal (down to a depth of $10 \mathrm{~m}$ ); almost all species can be found in either the high or mid-tidal zones, with only two exclusively in the low-tidal zone or deeper (and one of these is commonly found in shallow lagoons).

In terms of characteristics of the shellfish themselves, they range significantly in size, frequency, gregariousness, occurrence and mobility. Most are currently common to abundant along the Victorian coast, with one species, Ostrea angasi, rare generally, but abundant in its fairly limited estuarine or lagoon habitat. Most are gregarious to a greater or lesser degree, and occur in small groups to very dense beds. All but one of the rock substratum adapted species are mobile, while both soft substratum species are sessile. The largest species, Ostrea angasi, is also currently the most rare, and the rest of the species range from $25 \mathrm{~mm}$ to $85 \mathrm{~mm}$ for adults.

It is always risky to apply modern-day faunal distributional studies to Pleistocene situations and the present study has the usual difficulties in this regard. The coastline in the vicinity of Cape Duquesne was considerably different 10,000 years ago and it is difficult to accurately and independently model the nature of shellfish habitats in detail for that period. Nevertheless, on the basis of sea-bed mapping, geological studies and information from local crayfishermen, it is apparent that the shoreline off what is now Cape Duquesne would have been rocky, dominated by basalt boulders and platforms, with some sandy coves. This is currently a high-energy shoreline, bearing the brunt of high breaker waves, predominantly from the southwest (Short 1988:125); it was likely at least as energetic during the late-Pleistocene and early-Holocene. It is reasonable to conclude that the immediate early-Holocene coastal marine environment off what is now Cape Duquesne provided a favourable habitat for shellfish that prefer cold water, tolerate high energy waves and feed on algae that live on a rocky substratum.

Discovery Bay would have been likely dominated by high-energy sandy beaches as at present, with occasional rock outcrops and possibly lagoons, while Bridgewater Bay would not have existed as a water body; rather, a stretch of sandy beaches, possibly with backing lagoons, would have joined the southward-projecting Cape Bridgewater and Cape Nelson headlands. Patchy basalt outcrops and occasional offshore platforms would probably also have been present, and all would have been exposed to high-energy waves. 


\section{Subsistence}

Shellfish are a predictable resource in that the density and location of species of interest varies little from year to year (e.g. Meehan 1982:160), making them an ideal regular staple, especially on a short-term or seasonal basis. Very little evidence for the presence of other types of food was found in the excavations at Cape Duquesne, despite alkaline $\mathrm{pH}$ values conducive to the preservation of bone (Reitz and Wing 2008:140-141). It must be concluded that the economic basis of occupation at Cape Duquesne was largely shellfish, although non-economic factors are likely to have also influenced selection of this locality. The sustained and repeated usage of the locality for essentially the same purpose strongly indicates that shellfishing was an ongoing component of the subsistence economy.

If the proportions of shellfish species found in the middens are considered, the top three species, Turbo undulata, Cellana tramoserica and Austrocochlea concemerata, account for $92 \%$ of the total assemblage MNI, spanning the entire 2200-year period that middens were deposited on this landscape. These species are very alike in terms of habitat, all being found on intertidal rock platforms on medium to high-energy coasts (Table 8). They are also all mobile algae grazers, are gregarious, and occur in small to large groups. One difference between them is that while Austrochlea and Cellana tramoserica can be found in the high-tidal zone, often exposed to the air, and all three species occur in the mid-tidal zone, only Turbo undulata is commonly found in the sub-tidal zone down to a depth of $10 \mathrm{~m}$. The other notable difference is that while adult Turbo undulata average about $70 \mathrm{~mm}$ in diameter and Cellana tramoserica averages 60 $\mathrm{mm}$, Austrocochlea concemerata only average $25 \mathrm{~mm}$ in size.

Looking at proportions of shellfish species in the excavated middens more closely, the most common species by a considerable margin is Turbo undulata, at $61 \%$ of the entire assemblage MNI. One interpretation of the excavation results, in light of the likely shoreline habitat characteristics during the main period of occupation at Cape Duquesne ca. 10,000 cal BP and the current understanding of shellfish ecology, is that the occupants primarily targeted Turbo undulata, and that the specific rock-platform locations where Turbo undulata was to be found also held significant numbers of Cellana tramoserica and Austrocochlea concemerata, usually at shallower depths, and that these were secondary targeted species. The other rock-platform species represented in the assemblage were likely collected as bycatch during the main activity of obtaining Turbo undulata. To obtain meaningful amounts of fully grown Turbo undulata, some may be collected by wading, but complete immersion in the ocean would likely be necessary. If there were no Turbo undulata to hand while submerged in the very cold Southern Ocean, there would be considerable incentive to collect anything edible otherwise encountered (hence, the bycatch species in the assemblage).

During the latter period of occupation, it appears that there was a significant change in focus from mobile, intertidal rock-platform shellfish species that had to be individually located and collected by hand, to a sessile, sandy-beach species that occurred in large, highly dense beds. Donax deltoides are typically found in water-saturated sand, around $10-20 \mathrm{~cm}$ below the surface, and using bare feet to locate them and hands to pick them up, collectors may expect to get arms wet up to the elbows and legs wet to the knees, which is a radically different proposition to the collection of Turbo undulata in sub-tidal waters while being battered against a rock platform by enormous waves.

\section{Discussion}

\section{Relationship with contemporary early-Holocene inland sites}

In terms of their place in a larger-scale landscape settlement pattern, the three early- 
Holocene occupations at Cape Duquesne, Bridgewater South Cave and Koongine Cave represent repeated, short-term, small-group resource-extraction camps, with Bridgewater South Cave and Koongine Cave having a nearly exclusive focus on terrestrial mammals and Cape Duquesne on littoral invertebrates. The balance of the evidence suggests cold-season occupation for the inland caves and warm-season occupation for the open coastal landscape, although there is no absolute seasonal control on resource availability or access. In all three cases, food resources were killed or collected away from the camping area and brought back to the camps for processing and consumption. The cave sites, with their hunting emphasis, contain considerable evidence for stone working, which included wood working, tool manufacturing and maintenance. At the Cape Duquesne camps, stone working was a minimal activity. Viewed through general ethnographic patterns, the data could indicate a division of activity and site occupation by gender, with hunting and stone working providing a predominantly male emphasis at Bridgewater South Cave and Koongine Cave, while shellfishing and associated processing suggest a female activity focus at Cape Duquesne.

The distance from Bridgewater South Cave to the camping area at Cape Duquesne at $10,000 \mathrm{cal} \mathrm{BP}$ was $8 \mathrm{~km}$, with less than $1.2 \mathrm{~km}$ further south to the littoral resources on the shore. Given the contemporaneity of occupation of the two locations, and the two to three hour walk between them, it is conceivable that the same people occupied both sequentially, or even at the same time. With little effort, scenarios could be constructed involving: (1) small family groups spending time shellfishing on the coast while camped at Cape Duquesne and then moving on to Bridgewater South Cave to hunt terrestrial mammals; (2) mainly women, children and older people camping at Cape Duquesne and collecting shellfish, while a related party of men were hunting terrestrial resources out of a field camp in the Bridgewater South Cave; (3) groups of mainly men or women, in different hunting and foraging parties from asyet-unknown, larger base-camp locations, using Bridgewater South Cave and Cape Duquesne as temporary field camps, where activities concentrated on field processing food resources for transportation to the base camps.

All three sites should be viewed as indicative of early-Holocene short-term field camps in this region, along with even more ephemeral contemporary inland evidence of occupation at Blackfellows Waterhole (Richards 2004), Billimina Rockshelter and Drual Rockshelter (Bird and Frankel 2005), located to the northeast. This regional pattern of short-term, repeatedly occupied sites suggests a highly mobile, sparse human population in the early-Holocene.

\section{Comparison with late-Holocene midden structure and contents}

Recent research at a very large late-Holocene midden some $3 \mathrm{~km}$ to the northeast of Cape Duquesne, has revealed a distinct chronology of landscape usage and shellfishing patterns (Richards and Johnston 2004; Richards and Webber 2004). The Cape Bridgewater landscape contains Aboriginal midden deposits measuring up to $237,000 \mathrm{~m}^{2}$ in area, and with an estimated average thickness of $10 \mathrm{~cm}$ there may have been up to $23,700 \mathrm{~m}^{3}$ of midden at this location (Richards and Johnston 2004). In contrast, the Cape Duquesne landscape, although around half to one quarter the size of Cape Bridgewater, only contains small patches of visible midden deposit, measured at just over $1500 \mathrm{~m}^{2}$ and estimated to have been no more than $3000 \mathrm{~m}^{2}$ (including buried and destroyed deposits). Testing of the Cape Duquesne middens indicates a mean thickness of $4 \mathrm{~cm}$, providing an estimate of up to $120 \mathrm{~m}^{3}$ of early-Holocene midden deposit on this landscape, vs. 23,700 $\mathrm{m}^{3}$ at Cape Bridgewater, or 198 times as much midden at the latter.

Radiocarbon age determinations indicate an occupation span at Cape Bridgewater of some 3600 years, from ca. $4000 \mathrm{cal} \mathrm{BP}$ to ca. $400 \mathrm{cal} \mathrm{BP}$, with an estimated average of up to $6.6 \mathrm{~m}^{3}$ of shell midden deposition per year. In contrast, occupation of Cape Duquesne occurred over 
a span of 2200 years, resulting in an estimated midden deposition rate of up to $.06 \mathrm{~m}^{3}$ per year. The estimated average annualised rate of midden deposition on the late-Holocene Cape Bridgewater landscape is thus 110 times greater than the average annualised rate of midden deposition on the early-Holocene Cape Duquesne landscape.

\section{Comparison with late-Holocene shellfishing patterns}

At Cape Duquesne, there was a focus on one species, Turbo undulata, a relatively large sea snail that had to be collected by hand in the sub-tidal zone off wave-battered intertidal rock platforms. Two other species which had similar adaptations and habitat, although largely confined to the mid to high-tidal zones, were also collected, but to a lesser extent. Combined, the three top species in the assemblage, which were able to be collected at the same location, but at varying depths, comprised $92 \%$ of the MNI; almost all of the remaining species, which also could have been found in the same location, can be regarded as bycatch. The collection of sandy-shore species Donax deltoides occurred after the main period of landscape occupation and represents a switch to a new catchment, with Donax replacing Turbo as the dominant species.

The investigated sample from Cape Bridgewater totals 11,308 MNI, comprising 17 distinct taxa (vs. 11 taxa at Cape Duquesne); however, there was a concentration on mass collection and processing of one small species of shellfish found in sandy beaches, Paphies angusta (Narrow Wedge Shell). In the period 4000 to 1500 cal BP at Cape Bridgewater, 70\% of MNI were Paphies angusta, while in the period 1400-400 cal BP this species increased to 90\% of MNI (Richards and Johnston 2004:106). Significant numbers of both sandy and rocky substrate species were collected at Cape Bridgewater, so that while there was a major focus on one sandy-shore species, the fact that a distinct rocky-shore area was also accessed to collect rock-platform species indicates that these were deliberately targeted as supplemental species and not bycatch.

The economic focus on the Cape Bridgewater landscape was shellfish extraction, processing and consumption, which occurred on a large scale, repeatedly and over an extended duration (Richards and Johnston 2004:110). Aboriginal bands used this location as a base camp, undertaking a range of activities, probably on a semi-annual, seasonal (summer) basis for durations of a few weeks to a few months at a time (Richards and Johnston 2004:108-109). Cape Duquesne also had a focus on shellfish extraction, processing and consumption, and this also appeared to occur repeatedly over an extended duration and was probably semi-annual and seasonal in nature; however, this was a very small-scale activity that was targeted mainly towards a few species found in a few vertically stratified zones at intertidal rock platforms. In contrast to Cape Bridgewater, all of the evidence at Cape Duquesne indicates that small groups, on the scale of extended families, camped at this location for short periods of time, for durations of a few days to a few weeks at most.

\section{Conclusions}

Three natural phenomena allowed the formation and subsequent preservation of the Cape Duquesne Aboriginal landscape: (a) a cliff; (b) a steeply sloping sea bed; and (c) a sand ramp. The sand ramp joined the clifftop with the early-Holocene shoreline, providing an environmental setting that Aboriginal people turned into their own landscape, collecting marine littoral resources from the Southern Ocean and transporting them to their camping places at the top of Cape Duquesne for processing and consumption. Because of the steeply sloping sea bed, at $10,000 \mathrm{cal} \mathrm{BP}$, the clifftop location would have been only just over $1 \mathrm{~km}$ to the north and about $75 \mathrm{~m}$ above the shoreline, providing a highly convenient camping location with a commanding view over an extensive coastal plain. 
This is not an unusual occurrence of one isolated early midden; instead, the evidence from the Cape Duquesne landscape indicates that coastal occupation was a regular feature of the settlement-subsistence pattern in southwest Victoria from at least the onset of the Holocene.

The archaeological research at Cape Duquesne contributes to the study of socio-cultural complexity in southwest Victoria by providing a baseline dataset for comparisons with lateHolocene coastal Aboriginal landscape use, especially:

1. The physical nature of the middens, including size, composition and structure, indicating discrete patches of midden ranging up to $750 \mathrm{~m}^{2}$ in area, containing 11 shellfish taxa, stone artefacts and hearth features.

2. A firm chronology based on 15 radiocarbon dates, demonstrating repeated marine shell midden occupations of the area over a maximum 2500-year span (ca. 11,100 cal BP to ca. 8600 cal BP) with a focus on the period ca. 10,500-10,000 cal BP.

3. Statistics derived from midden measurements and chronology, such as annualised midden deposition rate, estimated at up to $.06 \mathrm{~m}^{3}$ per year.

4. The character of marine littoral resource exploitation, which was a highly patterned focus on three species that were available from high-tidal to sub-tidal zones at rock platforms. Other shellfish species were collected incidentally as they were encountered at these locations. The primary focus was on relatively $K$-selected shellfish that were individually collected and processed by hand prior to consumption.

5. The character of human occupation of the landscape; this was small scale and probably seasonal, indicating short-term reliance on shellfish as a food source by small groups of people.

In marked contrast, a nearby late-Holocene Aboriginal landscape at Cape Bridgewater, occupied some 5000 years after Cape Duquesne, contained a very large midden deposit with evidence for a concentration on mass collection and processing of one very small, sessile species of shellfish that was available in very large beds in the high-tidal zone. This late-Holocene midden had an annualised midden deposition rate that was estimated to be 110 times greater than at Cape Duquesne in the early-Holocene. The Cape Bridgewater midden itself is structurally different, being much larger and thicker, having huge areas of continuous midden deposit, while at Cape Duquesne the midden deposit is discontinuous, patchy and much thinner.

It must be concluded that there is no indication of complexity in the early-Holocene archaeological record at Cape Duquesne; in fact the evidence provides a textbook signature for generalised, highly mobile, egalitarian hunter-gatherers. This finding is consistent with other documented early-Holocene occupations in southwest Victoria, such as Bridgewater South Cave, Koongine Cave, Blackfellow's Waterhole, Billimina Rockshelter and Drual Rockshelter. It is also clear that something very different was happening in terms of Aboriginal coastal occupation and littoral resource use in this area during the late-Holocene in comparison with the early-Holocene. The late-Holocene occupations were more highly organised, and probably more tightly scheduled, by larger groups that stayed on the coast for longer periods, and who utilised a broader range of species while increasingly focusing over time on the mass collection and processing of one highly $r$-selected species. This pattern is entirely consistent with the lateHolocene appearance of semi-sedentary, high population density, complex, transegalitarian societies, as postulated by Lourandos (1980a, b, 1983, 1997) and Williams $(1985,1987,1988)$. 
It is also consistent with the results of Kershaw and his collaborators on the Mt Eccles lava flow.

\section{Acknowledgements}

The research reported in this paper resulted from fieldwork in 1995 and 2001 undertaken in a cultural heritage research, management and training partnership between the Gunditj Mirring Traditional Owners and Aboriginal Affairs Victoria.

I acknowledge with gratitude the Elders and members of the Gunditj Mirring Traditional Owners Aboriginal Corporation (and the Winda Mara Aboriginal Corporation, Gunditjmara Native Title Claimants and Kerrup Jmara Elders Corporation) who initiated the idea of archaeological investigations, protection and management for the Cape Duquesne Aboriginal landscape, and then followed through with strong support and action: Eileen Alberts, Damein Bell, Michael Bell, Denise Lovett, Mick Onus, Darryl Rose, Denis Rose, Ken Saunders and Theo Saunders. Special recognition is due to Denise Lovett and Darryl Rose for their superb job of organising and co-directing the 2001 field school. We thank the following 2001 field school participants from the Winda Mara Aboriginal Corporation who excavated at Cape Duquesne: John Bell, Darren Bell, Leonard Cooper, Keisha Day, John Kanoa, Jessica Lovett, Gordon Slade and Leon Walker.

I thank former and present senior managers of Aboriginal Affairs Victoria for funding and supporting the research and training under my direction: Terry Garwood, Jill Gallagher, Joy Elley, Tony Cahir, Ian Hamm and especially David Clark who originally guided me to Cape Duquesne. Many other present and former members of Aboriginal Affairs Victoria (including volunteers) provided important assistance and support during various phases of the research, including background research, excavations, mapping, labwork, map drafting and teaching students: Grant Cochrane, David Doyle, Joanna Freslov, Pam Gait, Simon Greenwood, Tania Hardy-Smith, Shawn Ilsley, Sharon Lane, Richard MacNeill, Rob McWilliams, Joanna Newby, Christina Pavlides, Jamie Reeves, Petra Schell, Harry Webber, Bianca Weir and Christine Williamson. I especially note the indispensable contributions from Joanne Jordan as assistant director of the 1995 investigations and Rochelle Johnston for her work on site in 1995 and 2001, for her Shell Midden A sediment analysis, and for detailed comments on a draft of this paper.

Parks Victoria staff generously supported this research, both through the timely provision of permits for conducting scientific research within the Discovery Bay Coastal Park and in numerous practical ways in the field.

Southwest TAFE provided an accredited teaching framework for the archaeological field school investigations in 2001, and 17 participants received Certificate II qualifications in Aboriginal Material Culture - Care and Management.

More recently, the School of Geography and Environmental Science, Monash University, has supported the final writing up of this chapter, especially my principal supervisor, Dr Ian McNiven, and Dr Bruno David who provided funding for several radiocarbon dates.

I thank an anonymous reviewer and the editors of this volume for their helpful comments on a draft of this chapter.

\section{References}

Australian Museum 2010. Molluscs. http://australianmuseum.net.au/Molluscs/, accessed 13 October 2010.

Barwick, D.E. 1984. Mapping the past: an atlas of Victorian clans 1835-1904. Aboriginal 
History 8:100-131.

Barwon Bluff Marine Sanctuary 2010. Life on the edge: a guide to the animals and plants of the Barwon Bluff Marine Sanctuary. http://www.barwonbluff.com.au/barwon_index.htm, accessed 13 October 2010.

Beaton, J.M. 1983. Does intensification account for changes in the Australian Holocene archaeological record? Archaeology in Oceania 18:94-97.

Beaton,J.M.1985. Evidence for a coastal occupation time-lag at Princess Charlotte Bay (North Queensland) and implications for coastal colonization and population growth theories for Aboriginal Australia. Archaeology in Oceania 20:1-20.

Beechey, D. 2009. The Seashells of New South Wales. Release 14, 1 October 2009. http:// seashellsofnsw.org.au/index.htm, accessed 17 September 2010.

Bird, C.F.M. and Frankel, D. 1991a. Chronology and explanation in western Victoria and south-east South Australia. Archaeology in Oceania 16:1-16.

Bird, C.F.M. and Frankel, D. 1991b. Problems in constructing a prehistoric regional sequence: Holocene south-east Australia. World Archaeology 23:180-192.

Bird, C.F.M. and Frankel, D. 1998. Pleistocene and Early Holocene archaeology in Victoria. A view from Gariwerd. The Artefact 21:48-62.

Bird, C.F.M. and Frankel, D. 2001. Excavations at Koongine Cave: Lithics and land-use in the Terminal Pleistocene and Holocene of South Australia. Proceedings of the Prehistoric Society 67:49-83.

Bird, C.F.M. and Frankel, D. 2005. An archaeology of Gariwerd from Pleistocene to Holocene in western Victoria. Tempus 8. St. Lucia: Anthropology Museum, University of Queensland.

Bird, C.F.M., Frankel, D. and van Waarden, N. 1998. New radiocarbon determinations from the Grampians-Gariwerd region, western Victoria. Archaeology in Oceania 33:31-36.

Bird, C.F.M., Frankel, D. and van Waarden, N. 1999. Prokrustes in Gariwerd. Archaeology in Oceania 34:86.

Bird,E.C.F.1993. The Coast of Victoria. The Shaping of Scenery. Melbourne: Melbourne University Press.

Boutakoff, N. 1963. The geology and geomorphology of the Portland area. Geological Survey of Victoria, Memoir 22. Melbourne: Government Printer.

Buckley, R. 1992. Victorian Coastal Sediment Survey, final report. Unpublished Report No. 92-03-15, Coastal Investigations Unit, Port of Melbourne Authority, Melbourne.

Builth, H., Kershaw, A.P., White, C., Roach, A., Hartney, L., McKenzie, M., Lewis, T. and Jacobsen, G. 2008. Environmental and cultural changes on the Mt Eccles lava-flow landscapes of southwest Victoria, Australia. The Holocene 18:413-424.

Cann, J.H., de Deckker, P. and Murray-Wallace, C.V. 1991. Coastal Aboriginal shell middens and their palaeoenvironmental significance, Robe Range, South Australia. Transactions of the Royal Society of South Australia 115:161-175.

Clark, D.J. 1979. The Gambieran Stone Tool Industry. Unpublished BA Honours thesis, Division of Prehistory, La Trobe University.

Coastal Management and Co-ordination Committee 1981. Western Coastal Study. Volume One, Resource Document. Melbourne: Department of Crown Lands and Survey.

Corris, P. 1968. Aborigines and Europeans in Western Victoria. Occasional Papers in Aboriginal Studies No 12, Ethnohistory Series No. 1. Canberra: Australian Institute of Aboriginal Studies.

Coutts, P.J.F. 1967. Wilson's Promontory, Victoria from prehistoric times to present. Unpublished $\mathrm{PhD}$ thesis, Australian National University.

Critchett, J. 1990. A Distant Field of Murder. Western District Frontiers 1834-1848. Melbourne: Melbourne University Press. 
Critchett,J. 1998. Untold Stories. Memories and Lives of Victorian Kooris. Melbourne: Melbourne University Press.

Cupper, M.L., White, S. and Neilson, J.L. 2003. Quaternary: Ice Ages - Environments of Change. In: Birch, W.D. (ed), Geology of Victoria (3rd ed.), pp. 337-360. Geological Society of Australia Special Publication 23. Melbourne: Geological Society of Australia.

Curr, E.M. 1886-87. The Australian Race: its Origins, Languages, Customs, Places of Landing in Australia and the Routes by Which it Spread ItselfOver that Continent, Volumes 1-4. Melbourne: Victorian Government Printer.

Dakin, W.J. 1976. Australian Seashores. Sydney: Angus and Robertson Publishers.

Dakin, W.J. 1987. Australian Seashores. Fully revised and updated by I. Bennett. Sydney: Angus and Robinson.

Davey, K. 2000. Life on Australian seashores. http://www.mesa.edu.au/friends/ seashores, accessed 10 September 2005.

David, B., Barker, B. and McNiven, I.J. (eds) 2006. The Social Archaeology of Australian Indigenous Societies. Canberra: Aboriginal Studies Press.

Dawson,J. 1881. Australian Aborigines. The Languages and Customs of Several Tribes of Aborigines in the Western District of Victoria, Australia. Melbourne: George Robertson.

Dawson, J. 1887. Mr. Curr's work on the Australian race. Letter to Editor of The Argus, 21 October.

Debney, T. and Cekalovik, H. 2001. Portland Wind Energy Project EES, cultural heritage study. In: Portland Wind Energy Project, Environment Effects Statement and Planning Report, Supplemental Volume C, pp. 165-239. Blue Wind Energy, Pacific Hydro and Sinclair Knight Merz.

Douglas, J.G. 1979. Explanatory notes on the Portland 1:250,000 Geological Map. Geological Survey Report No. 62. Melbourne: Geological Survey of Victoria.

Edwards, W.H. 1987. Leadership in Aboriginal society. In: Edwards, W.H. (ed), Traditional Aboriginal Society: a Reader, pp. 153-173. Melbourne: MacMillan.

Everett, C. 1998. An archaeological investigation of proposed windfarm sites, Portland, Victoria. Unpublished report, Aboriginal Affairs Victoria, Melbourne.

Frankel, D. 1986. Excavations in the lower southeast of South Australia: November 1985. Australian Archaeology 22:75-87.

Frankel,D. 1991. First-order radiocarbon dating of Australian shell-middens. Antiquity 65:571574.

Gibbons, F.R. and Downes, R.G. 1964. A Study of the Land in South Western Victoria. Melbourne: Soil Conservation Authority Victoria.

Godfrey, M.C.S. 1980. An archaeological survey of the Discovery Bay Coastal Park, Volumes 1 and 2. Unpublished report for the National Parks Service, Melbourne.

Godfrey, M.C.S. 1984. Seasonality and shellfishing at Discovery Bay, Victoria. Unpublished MA thesis, Division of Prehistory, La Trobe University, Bundoora.

Godfrey, M.C.S. 1989. Shell midden chronology in south western Victoria: Reflections of change in prehistoric population and subsistence? Archaeology in Oceania 24(2):65-79.

Godfrey, M.C.S. 1994. The archaeology of the invisible. Seasonality and shellfishing at Discovery Bay Victoria: the application of oxygen isotope analysis. Unpublished PhD thesis, School of Chemistry, La Trobe University, Bundoora.

Godfrey, M.C.S. 1996. The Yellow Rock project. Unpublished report, Aboriginal Affairs Victoria, Melbourne.

Godfrey, M.C.S. 2000. Access and protection? An archaeological survey of the Bridgewater Bay Dune. Unpublished report, Aboriginal Affairs Victoria, Melbourne.

Godwin, L. 1980. What you can do with 27,000 pieces of bone: A taphonomic study of the 
vertebrate fauna of Bridgewater Cave South. Unpublished BA (Honours) thesis, University of New England, Armidale.

Grier, C., Kim, J. and Uchiyama, J. 2006. Beyond Affluent Hunter-Gatherers: Rethinking HunterGatherer Complexity. Proceedings of the 9th Conference of the International Council of Archaeozoology, Durham, August 2002. Oxford: Oxbow Books.

Hayden, B. 1995. Pathways to power: Principles for creating socioeconomic inequalities. In: Price, T.D. and Feinman, G.M. (eds), Foundations of Social Inequality, pp. 15-86. New York: Plenum Press.

Hayden, B. 2006. Comment on Constraints on the development of enduring inequalities in late Holocene Australia by I. Keen. Current Anthropology 47(1):21-22.

Head, L. 1985. Pollen analysis of sediments from the Bridgewater Caves archaeological site, southwestern Victoria. Australian Archaeology 20:1-15.

Hiatt, L.R. 1996. Arguments About Aborigines. Australia and the Evolution of Social Anthropology. Cambridge: Cambridge University Press.

Hiscock, P. 2008. The Archaeology of Ancient Australia. London: Routledge.

Howitt, A.W. 1887. The Australian Aborigines. Letter to the editor of The Argus, 28 October.

Howitt, A.W. 1904. The Native Tribes of South-East Australia. London: Macmillan and Co. Ltd. (Facsimile edition, Aboriginal Studies Press, Canberra 1996.)

Johnston, R. 1996. Sediment report for the Moorabool Basin and Cape Duquesne Statewide Survey investigations. Unpublished report, Aboriginal Affairs Victoria, Melbourne.

Keen, I. 2006. Constraints on the development of enduring inequalities in late Holocene Australia. Current Anthropology 47(1):7-38.

Kenley, P.R. 1976. Southwestern Victoria. In: Douglas, J.G. and Ferguson, J.A. (eds), Geology of Victoria, pp. 290-298. Melbourne: Geological Society of Australia.

Kershaw, A.P. (ed) 2004. Environmental History of the Newer Volcanic Province of Victoria. Proceedings of the Royal Society of Victoria, Vol. 116, No. 1. Melbourne.

Kershaw, A.P. and Lewis, T. 2011. Environmental history of the Budj Bim landscape: implications for Aboriginal occupation and management and World Heritage nomination. Paper presented at the Budj Bim World Heritage Symposium, Heywood Victoria.

Kershaw, A.P., Tibby, J., Penny, D., Yezdani, H., Walkley, R., Cook, E.J. and Johnston, R. 2004. Latest Pleistocene and Holocene vegetation and environmental history of the Western Plains of Victoria, Australia. In: Kershaw, A.P. (ed), Environmental History of the Newer Volcanic Province of Victoria, pp. 139-161. Proceedings of the Royal Society of Victoria, Vol. 116, No. 1. Melbourne.

Koyama, S. and Thomas, D.H. (eds) 1981. Affuent Foragers: Pacific Coasts East and West. Senri Ethnological Series 9. Osaka: National Museum of Ethnology.

Land Conservation Council 1981. Report on the South-Western Area, District 1 - Review. Melbourne: Land Conservation Council.

Lourandos, H. 1976. Aboriginal settlement and land use in south western Victoria: a report on current field work. The Artefact 1:174-193.

Lourandos, H. 1977. Aboriginal spatial organization and population: South western Victoria reconsidered. Archaeology and Physical Anthropology in Oceania 12:202-225.

Lourandos, H.1980a. Forces of change. Unpublished PhD thesis, Department of Anthropology, University of Sydney.

Lourandos, H. 1980b. Change or stability?: Hydraulics, hunter-gatherers and population in temperate Australia. World Archaeology 11:254-266.

Lourandos, H. 1983. Intensification: a Late Pleistocene-Holocene archaeological sequence from south western Victoria. Archaeology in Oceania 18:81-97.

Lourandos, H. 1984. Review of Australian Aborigines: the languages and customs of several 
tribes of Aborigines in the Western District of Victoria, Australia by James Dawson. Aboriginal History 8:215-219.

Lourandos, H. 1985a. Intensification and Australian prehistory. In: Price, T.D. and Brown, J.A. Prehistoric Hunter-Gatherers - The Emergence of Cultural Complexity, pp. 385-423. Academic Press, Inc.

Lourandos, H. 1985b. Problems with the interpretation of late Holocene changes in Australian prehistory. Archaeology in Oceania 20:37-39.

Lourandos, H. 1987. Swamp managers of southwestern Victoria. In: Mulvaney, D.J. and White, J.P. (eds), Australians to 1788 (Vol. 1), pp. 292-307. Sydney: Fairfax, Syme and Weldon Associates.

Lourandos, H. 1988. Palaeopolitics: Resource intensification in Aboriginal Australia and Papua New Guinea. In: Ingold, T., Riches, D. and Woodburn, J. (eds), Hunters and gatherers 1: History, evolution, and social change, pp. 148-160. Oxford: Berg.

Lourandos, H. 1993. Hunter-gatherer cultural dynamics: long- and short-term trends in Australian prehistory. Journal of Archaeological Research 1(1):67-88.

Lourandos, H. 1996. Change in Australian prehistory: scale, trends and frameworks of interpretation. In: Lilley, I., Ross, A. and Ulm, S. (eds), Proceedings of the 1995 Australian Archaeological Association Conference, pp. 15-21. Tempus 6.

Lourandos, H. 1997. Continent of Hunter-Gatherers. New Perspectives in Australian Prehistory. Cambridge: Cambridge University Press.

Lourandos, H. and Ross, A. 1994. The great 'intensification debate': its history and place in Australian archaeology. Australian Archaeology 39:54-63.

Macpherson, J.H. and Gabriel, C.J. 1962. Marine Molluscs of Victoria. Melbourne: Melbourne University Press/Museum of Victoria.

McBryde, I. 1984. Exchange in south eastern Australia: an ethnohistorical perspective. Aboriginal History 8:132-153.

McCormac, F.G., Hogg, A.G., Blackwell, P.G., Buck, C.E., Higham, T.F.G. and Reimer, P.J. 2004. SHCal04 southern hemisphere calibration 0-11.0 cal kyr BP. Radiocarbon 46:10871092.

McNiven, I.J., David, B. and Lourandos, H. 1999. Long-term Aboriginal use of western Victoria: Reconsidering the significance of recent Pleistocene dates for the GrampiansGariwerd region. Archaeology in Oceania 34:83-85.

Meehan, B. 1982. Shell Bed to Shell Midden. Canberra: Australian Institute of Aboriginal Studies.

NSW Fisheries 2010. Native oyster Ostrea angasi. NSW Department of Primary Industries, Fishing and Aquaculture. http://www.dpi.nsw.gov.au/fisheries/recreational/ saltwater/swspecies/flat-oyster, accessed 13 October 2010.

O'Sullivan, B.W. 1980. The fertility of the Port Lincoln Oyster (Ostrea angasi sowerby) from West Lakes, South Australia. Aquaculture 19:1-11.

Owens, D. and Hayden, B. 1997. Prehistoric rites of passage: a comparative study of transegalitarian hunter-gatherers. Journal of Anthropological Archaeology 16:121-161.

Price, T.D. and Brown, J.A. (eds) 1985. Prehistoric Hunter-Gatherers - The Emergence of Cultural Complexity. San Diego: Academic Press, Inc.

Reimer, P.J., Baillie, M.G.L., Bard, E., Bayliss, A., Beck, J.W., Blackwell, P.G., Bronk Ramsey, C., Buck, C.E., Burr, G.S., Edwards, R.L., Friedrich, M., Grootes, P.M., Guilderson, T.P., Hajdas, I., Heaton, T.J., Hogg, A.G., Hughen, K.A., Kaiser, K.F., Kromer, B., McCormac, F.G., Manning, S.W., Reimer, R.W., Richards, D.A., Southon, J.R., Talamo, S., Turney, C.S.M., van der Plicht, J., Weyhenmeyer, C.E. 2009. Intcal09 and Marine09 radiocarbon age calibration curves, 0-50,000 Years Cal BP. Radiocarbon 51:1111-1150. 
Reitz, E.J. and Wing, E.S. 2008. Zooarchaeology, Second Edition. Cambridge Manuals in Archaeology. Cambridge: Cambridge University Press.

Richards, T. 2004. Blackfellows Waterhole 1 - Aboriginal Pre-Contact Site Excavation. In: Webber, H. and Richards, T. (eds), Barrabool Flora and Fauna Reserve Aboriginal Heritage Investigation and Training Project, pp. 23-31. Unpublished Report on Activities of the Aboriginal Community Heritage Investigations Program. Aboriginal Affairs Victoria, Melbourne.

Richards, T. and Johnston, R. 2004. Chronology and evolution of an Aboriginal landscape at Cape Bridgewater, south west Victoria. The Artefact 27:97-112.

Richards, T. and Jordan, J. 1996. Archaeological investigations at Cape Bridgewater, Victoria: management recommendations and preliminary excavation report. Unpublished report, Aboriginal Affairs Victoria, Melbourne.

Richards, T. and Webber, H. (eds) 2004. Cape Bridgewater Aboriginal Cultural Heritage Field School. Contributions by Thomas Richards, Michael Godfrey, Harry Webber, Rochelle Johnston, Richard MacNeill and Michael Westaway. Unpublished report, Aboriginal Affairs Victoria, Melbourne.

Rosengren, N. 2001a. Geotechnical and Geomorphological Issues. Pacific Hydro Portland Wind Energy Project EES. Sinclair Knight Merz.

Rosengren, N. 2001b. Supplementary Report - Geomorphological Indicators of Potential Archaeological Sites. Appendix 6, Pacific Hydro Limited Portland Wind Energy Project EES, Cultural Heritage Study Phase 2. Biosis Research.

Schell, P. 2000a. Cape Bridgewater and Bridgewater Bay Aboriginal cultural heritage review - Volume 1: heritage management. Unpublished report, Aboriginal Affairs Victoria, Melbourne.

Schell, P. 2000b. Cape Bridgewater and Bridgewater Bay Aboriginal cultural heritage review - Volume 2: Aboriginal Cultural Heritage Survey. Unpublished report, Aboriginal Affairs Victoria, Melbourne.

Short, A.D. 1988. Holocene coastal dune formation in Southern Australia: a case study. Sedimentary Geology 55:121-142.

Simmons, S. and Djekic, A. 1981. Alcoa Portland Aluminium Smelter Environmental Studies Report No. 2, supplementary archaeological survey. Unpublished report, Aboriginal Affairs Victoria, Melbourne.

Sloss, C.R., Murray-Wallace, C.V. and Jones, B.G. 2007. Holocene sea-level change on the southeast coast of Australia: a review. The Holocene 17:999-1014.

Species Bank 2010. Ostrea angasi. Australian Government, Department of the Environment, Water, Heritage and the Arts. http://www.environment.gov.au/cgi-bin/species-bank/ sbank-treatment.pl?id=69271, accessed 27 May 2010.

Stuiver, M. and Reimer, P.J. 1993. Extended 14C database and revised CALIB radiocarbon calibration program. Radiocarbon 35:215-230.

Stuiver, M., Reimer P.J. and Reimer R. 2011. CALIB Radiocarbon Calibration Program rev.6.0.1. http://calib.qub.ac. uk/calib, accessed May 2011.

Tibby,J., Kershaw,A.P., Builth,H.,Philibert,A. and White,C.2006. Environmental change and variability in southwestern Victoria: changing constraints and opportunities for occupation and land use. In: David, B., Barker, B. and McNiven, I.J. (eds), The Social Archaeology of Australian Indigenous Societies, pp. 354-369. Canberra: Aboriginal Studies Press.

Webb, C. 1995. An evaluation of the archaeological resources of six lightstation reserves in Victoria: Cape Nelson, Cape Otway, Cape Schanck, Wilsons Promontory, Point Hicks, Gabo Island. Unpublished report, Aboriginal Affairs Victoria, Melbourne.

Wentworth, C.K. 1933. The shapes of rock particles: a discussion. Journal of Geology 41:306- 
309.

Wesson, J.P and Clark, D. 1980. Alcoa Portland Aluminium Smelter Working Paper Number 2, archaeology. Unpublished report, Aboriginal Affairs Victoria, Melbourne.

Williams, E. 1985. Wet underfoot? Earth mound sites and the recent prehistory of southwestern Victoria. Unpublished $\mathrm{PhD}$ thesis, Australian National University.

Williams, E. 1987. Complex hunter-gatherers: a view from Australia. Antiquity 61:310-321.

Williams, E. 1988. Complex Hunter-Gatherers: a Late Holocene Example from Temperate Australia. British Archaeological Reports, International Series 423. Oxford.

Wilson, B.R. and Gillett, K. 1979. A Field Guide to Australian Shells Prosobranch Gastropods. Sydney: A.H. \& A.W. Reed Pty Ltd.

Wilson, B.R. and Gillett, K. 1980. Australian Shells. Sydney: A.H. \& A.W. Reed Pty Ltd.

Witter, D. 1977. The archaeology of the Discovery Bay area, Victoria. In: A collection of papers presented to ANZAAS 1977, Vol. 2, pp. 51-72. Memoirs of the Victorian Archaeological Survey. Melbourne: Ministry for Conservation. 